Discussion Paper No. 13-037

\title{
Poaching and Firm-sponsored Training: First Clean Evidence
}

Jens Mohrenweiser, Thomas Zwick, and Uschi Backes-Gellner

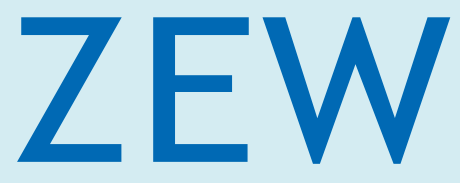

Zentrum für Europäische Wirtschaftsforschung $\mathrm{GmbH}$

Centre for European

Economic Research 
Discussion Paper No. 13-037

\title{
Poaching and Firm-sponsored Training: First Clean Evidence
}

\author{
Jens Mohrenweiser, Thomas Zwick, \\ and Uschi Backes-Gellner
}

Download this ZEW Discussion Paper from our ftp server:

http://ftp.zew.de/pub/zew-docs/dp/dp13037.pdf

Die Discussion Papers dienen einer möglichst schnellen Verbreitung von neueren Forschungsarbeiten des ZEW. Die Beiträge liegen in alleiniger Verantwortung der Autoren und stellen nicht notwendigerweise die Meinung des ZEW dar.

Discussion Papers are intended to make results of ZEW research promptly available to other economists in order to encourage discussion and suggestions for revisions. The authors are solely responsible for the contents which do not necessarily represent the opinion of the ZEW. 


\section{Nontechnical Summary}

Human capital investments of firms impose the risk that outsider firms poach trained worker because, in contrast to real capital investments, firms do not have the right of disposal for human capital investments. Since firms invest in general human capital, economic theory discusses how market imperfections create partial monopsony power for training firms. Such monopsony power permits general human capital investments of firms and reduce the poaching probability.

However to date, there have not been any empirical studies investigating the existence and extent of poaching after general human capital investments. This paper solves the empirical challenges to identify poaching and shows that around three per cent of the German apprenticeship training firms are poaching victims. Poaching is more likely to be observed in large firms that pay high earnings, whereas smaller firms that pay lower earnings are able to retain their most productive apprenticeship graduates.

This finding contrasts common arguments stating that low-earnings firms are more likely to be poaching victims. Instead, a firm's current economic status determines the likelihood of becoming a poaching victim. During a downsizing period, training firms may not be able to make counter-offers for apprenticeship graduates that they would like to employ. Workforce reduction signals to outsider firms that they can hire high-quality employees for relatively small earnings premiums. Finally, we find that poaching victims respond to poaching by slightly reducing the share of new apprentice intakes, but they do not adjust earnings for apprenticeship graduates in their first jobs as skilled employees.

We conclude that the overall importance of poaching on expected returns to apprenticeship training and firms’ training decisions seems to be negligible. 


\section{Das Wichtigste in Kürze}

Wenn Betriebe in Aus- und Weiterbildung investieren, gehen sie das Risiko einer Abwerbung der ausgebildeten Fachkräfte durch Konkurrenten ein, da die Betriebe, im Gegensatz zu Sachkapitalinvestitionen, durch die Aus- und Weiterbildungsinvestitionen kein Verfügungsrecht an ihrer Investition erhalten. Daher werden seit vielen Jahren Marktmechanismen diskutiert, welche eine Investition der Betriebe in das Humankapital der Mitarbeiter erklären. Diese theoretischen Modelle nutzen Marktunvollkommenheiten, um eine Monopsonmacht der Ausbildungsbetriebe zu modellieren, welche die Bildungsinvestitionen möglich macht. Durch diese Marktunvollkommenheiten kann die Abwerbung ausgebildeter Fachkräfte minimiert werden.

Über die tatsächliche Verbreitung von Abwerbungen auf dem Arbeitsmarkt ist bisher jedoch empirisch nichts bekannt. Der vorliegende Beitrag löst die empirischen Probleme zur Identifikation von Abwerbung und zeigt, dass auf dem deutschen Ausbildungsmarkt nur ca. 3 Prozent der Ausbildungsfirmen von Abwerbung betroffen sind. Diese betroffenen Betriebe sind jedoch im Durchschnitt eher große Betriebe mit hoher Ausbildungsneigung, die überdurchschnittliche Löhne zahlen als ihre Konkurrenten.

Dieser Befund widerspricht bisherigen Vermutungen, dass kleinere Firmen eher von Abwerbung betroffen sind. Von Abwerbung betroffene Betriebe befinden sich jedoch größtenteils in einer Phase temporären Arbeitskräfteabbaus und sind daher nicht in der Lage, Abwerbungsinitiativen von anderen Firmen zu unterbinden. Die einmalige Abwerbung von Absolventen der beruflichen Erstausbildung hat jedoch keinen Einfluss auf die Ausbildungsneigung und die Löhne der Facharbeiter. Allerdings reduzieren die Betriebe, die von Abwerbung betroffen wurden, die Anteil der Ausbildungsstellen an der Gesamtbeschäftigung ein wenig.

Diese Ergebnisse zeigen, dass die Relevanz von Abwerbung auf dem Ausbildungsmarkt auf die erwarteten Rückflüsse von Ausbildungsinvestitionen und die Ausbildungsneigung der Betriebe in Deutschland vernachlässigbar ist. 


\title{
POACHING AND FIRM-SPONSORED TRAINING: FIRST CLEAN EVIDENCE*
}

\author{
Jens Mohrenweiser (ZEW Mannheim) \\ Thomas Zwick (Würzburg University, ZEW Mannheim and ROA Maastricht) \\ Uschi Backes-Gellner (University of Zurich)
}

This version: May 2013

\begin{abstract}
:
A series of seminal theoretical papers argues that poaching of employees may hamper company-sponsored general training. However, the extent of poaching, its determinants and consequences, remains an open empirical question. We provide a novel empirical identification strategy for poaching and investigate its causes and consequences. We find that only a small number of training firms in Germany are poaching victims. Firms are more likely to poach employees during an economic downturn. Training firms respond to poaching by lowering the share of new apprentice intakes in the following years.
\end{abstract}

JEL Codes: J24, M51, M53

Key words: poaching, company sponsored training, recruiting, apprenticeship

\footnotetext{
* Corresponding author Jens Mohrenweiser: mohrenweiser@zew.de. Telephone: 00496211235160 We are grateful for the discussion and comments by Giorgio Brunello, Simon Janssen, Raymond Montizaan, Christian Pfeifer, Dario Pozzoli, Paul Ryan, Stefan Wolter, and Ludger Wössmann. The research was partly supported by the Swiss Federal Office for Professional Education and Technology through its Leading House on Economics of Education, Firm Behaviour and Training Policies. We thank the Research Data Centre (FDZ) of the Federal Employment Agency at the Institute for Employment Research for the data access and the support with analysis of the LIAB data. Data access was via guest research spells at FDZ and afterwards via controlled data remote access at the FDZ. The data basis of this paper is the LIAB longitudinal version 2.
} 


\section{Introduction}

Employers often pay for employee training even if accumulated skills are general and transferable to other employers (Barron et al., 1999; Loewenstein and Spletzer, 1999; Booth and Bryan, 2005; Bassanini et al., 2007). A number of theoretical studies have analysed incentives for companies to sponsor training in general human capital in situations where other firms can poach trained employees. If poaching occurs, the training firm loses its training investment and the raiding firm can meet its skill demand without paying for training. Consequently, poaching and the threat of poaching can lead to underinvestment in training by firms concerned about losing their investment. Theoretical models predict a coexistence of poaching and firm-sponsored general training - training costs pay off because the poaching probability is small and the majority of trainees stay with the training firm (Stevens, 1996, 2001; Acemoglu and Pischke, 1999a, 1999b; Booth and Zoega, 2004; Leuven, 2005; Lazear, 2009).

To date, there have not been any empirical studies investigating the existence and extent of poaching (Pischke, 2007; Brunello and De Paola, 2009). The main reason for this remarkable gap in the literature is difficulty in identifying poached trainees. There are two identification requirements: first, the training firm has to have an interest in retaining the training participant and, second, an outsider firm must be willing to pay higher earnings than the training participant would get at the training firm.

This paper introduces a novel approach to solve these empirical challenges and identifies poached trainees by exploiting several particularities of the German apprenticeship training system. This system mandatorily prescribes transferable skills which must be trained in each occupation in each training year. This ensures that apprentices perform and learn the same type of tasks. We argue that therefore earnings differences during the training period within one firm and occupation are related to relative productivity differences between apprentices. We exploit earning variance to identify the interest of training firms to retain apprenticeship graduates.

We infer that the training firm wishes to retain a leaving apprenticeship graduate if the graduate receives higher earnings at the end of the apprenticeship than his or her staying peers (this is our first poaching condition - interest to keep). The outsider firm poaches if the leaving apprenticeship graduate earns more with the new firm than any of the staying apprenticeship graduates (second poaching condition - earnings mark-up). 
Our empirical analysis shows that around 3 per cent of training firms are poaching victims. We observe that poaching and raiding firms are more likely to be large firms that pay high earnings, whereas smaller firms that pay lower earnings are able to retain their most productive apprenticeship graduates. This finding contrasts common arguments stating that low-earnings firms are more likely to be poaching victims. Instead, a firm's current economic status determines the likelihood of becoming a poaching victim. During a downsizing period, training firms may not be able to make counter-offers for apprenticeship graduates that they would like to employ. Workforce reduction signals to outsider firms that they can hire highquality employees for relatively small earnings premiums. Thus, raiding firms exploit current weaknesses of training firms and hire well-trained apprenticeship graduates they otherwise would not have been able to attract. Finally, we find that poaching victims respond to poaching by slightly reducing the share of new apprentice intakes, but they do not adjust earnings for apprenticeship graduates in their first jobs as skilled employees.

The poaching risk seems to be low in Germany and caused mainly by temporary downsizing of poaching victims. Therefore, we conclude that poaching has no strong influence on the expected returns from training, and hence firms’ training decisions.

The remainder of this paper is organised as follows: The next section reviews the literature. The third and fourth sections briefly describe the institutional setting of apprenticeship training in Germany and the data. Afterwards, we present our identification strategy for poached trainees and describe firms that are poaching victims in comparison with raiding firms and firms not affected by poaching. The seventh section analyses the response to poaching. The last sections discuss consequences for training markets and conclude.

\section{Background Discussion}

There is a long tradition of theoretical papers analysing firms' incentives to invest in the skills of their employees. The main argument for firms' investment in general human capital of employees is that labour market imperfections create a wedge between employees' posttraining earnings and productivity, and therefore allow firms to recoup training investments ${ }^{1}$. However, these market imperfections can simultaneously promote poaching when a raiding firm can earn a rent on the trained skills of a worker by outbidding earnings paid by the training firm (Stevens, 1994; Acemoglu and Pischke, 1999a, 1999b; Booth and Zoega, 2004; Leuven, 2005). The transferability of the acquired general skills between firms and the

\footnotetext{
${ }^{1}$ These models require two conditions: firms earn profits on workers and these profits increase with training level (Acemoglu and Pischke, 1999a; Leuven, 2005).
} 
visibility or transparency of the skills for outsider firms determines the probability of an outside offer and, hence, poaching (Lazear, 1986; Stevens, 1996, 2001) ${ }^{2}$. Poaching is only a problem if the future employment is ex-ante non-contractible or trained employees do not have to repay training investments.

Even if poaching and company-sponsored training can coexist, most theoretical contributions conclude that poaching hampers training investment in visible and transferable skills because a part of the return from that investment accrues to the raiding firm. The training firm only invests until marginal costs of training equal expected marginal benefits. Therefore, (the threat of) poaching might lead to a lower number of trainees or even to a non-training equilibrium (Stevens, 1996, 2001; Acemoglu and Pischke, 1999a, 1999b; Booth and Zoega, 2004; Leuven, 2005).

A number of contributors characterise strategies to prevent poaching. Training firms can get a reputation for training quality and credibly offer long-term contracts (Sadowski, 1980; Moen and Rosen, 2004). Also, firms may use training investment as a commitment device to reduce turnover (Backes-Gellner and Tuor, 2010). Cahuc et al. (1990) split firms with training investments into a group that poaches (dominating firms) and a group that loses some of their trained employees although this incurs a loss (dominated firms). They show that poaching does not necessarily replace a firm's own training efforts ${ }^{3}$.

Although theoretical models show the existence of an equilibrium between poaching and training, the identification of the existence, extent and consequences of poaching essentially remains an empirical question. So far, empirical papers have shown only that employers pay for the costs of training even if the accumulated skills can be transferred to other employers (Barron et al., 1999; Loewenstein and Spletzer, 1999; Booth and Bryan, 2005; Bassanini et al., 2007) ${ }^{4}$. However, some previous studies provide indirect evidence that poaching might exist. Booth and Bryan (2005) show that employees' earnings increases at subsequent employers exceed earnings increases for training firms if the employees reported company-

\footnotetext{
${ }^{2}$ A growing literature analyses the use of counter-offers. In Lazear (1986) for instance, outside offers are only made if the alternative employer is informed and the worker's productivity exceeds the worker's wage. The employing firm then either matches the offer if productivity is unknown or counters with a wage equal to the known productivity of the worker to the firm, which includes a firm-specific component. The raiding firm is successful in those cases when this firm-specific component is negative. Postel-Vinay and Robin (2004) show a "dual labour market” where some firms commit to an offer-matching policy and other firms commit to a policy of never making counter-offers. Barron et al. (2006) look at what conditions cause firms to use selective counteroffers.

${ }^{3}$ See also Combes and Duranton (2006) for a similar approach.

${ }^{4}$ Furthermore, Picchio and van Ours (2011) show that labour market flexibility (or lower search frictions) slightly reduces the incentives of firms to invest in training.
} 
sponsored training in general skills during the previous year. Similarly, Loewenstein and Spletzer (1999) show that employers reward skills acquired during previous employment.

Moreover, recent empirical studies show that firms typically pay more if they hire employees from direct competitors (Kampkötter and Sliwka, 2011). Parrotta and Pozzoli (2012) stress that poaching can be profitable for raiding firms. They show that hiring highly educated employees from rivalling firms can increase the value added of hiring firms by 1-2 per cent. Finally, Mühlemann and Wolter (2011) discuss the potential threat of poaching on firmsponsored general training in dense regional labour markets.

\section{Institutional Setting}

An empirical assessment of poaching and its impact on company-sponsored training requires an institutional framework which allows researchers to investigate whether firms pay for training in transferable and visible skills. The German apprenticeship training system provides a unique institutional framework that we will describe in detail in this section. Based on this institutional framework, we describe the necessary data in the next section and the precise identification of poaching victims in the fifth section.

Apprenticeship training in Germany traditionally provides the highest professional education degree for about two-thirds of the German workforce and is the backbone of medium-skilled occupational training. It is subject to a curriculum laid down in the Vocational Training Act and occupational specific training curricula. The Vocational Training Act describes the length of training, necessary equipment and requirements for training firms. Training firms must fulfil these requirements to get a permit for apprenticeship training granted by the Chambers of Industry and Commerce or the Chambers of Craft. The training curricula describe minimum skills for successful graduation in each training occupation. Apprentices receive graded skill certificates at the end of the training period. The Chambers observe training quality in each enterprise and administer the final exam on the practical part of the skills examination. The theoretical part is administered and graded by publicly funded and controlled vocational schools. Therefore, independent public bodies administer the theoretical and practical exams and survey the minimum skills acquired during apprenticeship training.

This institutional framework of apprenticeship training in Germany includes all following necessary ingredients required for identifying poaching:

First, it offers a consistent and unambiguous definition of training across firms. Apprenticeship graduates in different firms who are in the same occupation have comparable 
and guaranteed minimum skills that are monitored and examined by institutions independent of the training firms.

Second, compliance with the training regulations means that training is visible to outsider firms. This is guaranteed by the documented and transparent training curriculum and graded final exams documenting theoretical, social and practical skills. Therefore, an outsider firm knows the skill level of an apprenticeship graduate in a given occupation and can assess the quality of the applicant on the basis of the grades.

Third, skills are not only observable but also transferable. Institutional requirements severely limit firms' ability to reduce general content during apprenticeship training below a certain level ${ }^{5}$.

Fourth, re-payment of training costs by apprenticeship graduates who leave a firm is not permitted by law and future employment of apprenticeship graduates is non-contractible. Apprenticeship training contracts legally terminate at the day after the final exam and employment has to be negotiated at the end of the apprenticeship.

Fifth, apprenticeships are a training investment for some occupations, although this differs significantly between occupations. Apprentices in blue-collar manufacturing occupations are considered to require substantial training investment by firms. Schönfeld et al. (2010) found that investment costs for blue-collar apprentices are on average three times higher than those for white-collar apprentices. However, white-collar apprentices have been reported to be more productive during their apprenticeships and to recoup (most of) their training costs during the apprenticeship training period (Mohrenweiser and Zwick, 2009). Therefore, poaching is a threat to the willingness to train in expensive blue-collar occupations, whereas for cheaper white-collar occupations, poaching might be a minor problem.

Sixth, apprenticeship graduates who start their first job are a relatively homogeneous group in terms of age, tenure and prior education. Therefore, initial labour market conditions - an unknown and heterogeneous job history between stayers and movers and differences in selectivity at labour market entry (Flinn, 1986; Kahn, 2013) - do not apply because apprentices usually have no prior labour market experience and come directly from school. The graduates all started their training at the same point in time (and therefore there are no differences in occupation selectivity during the business cycle) and their contracts end at the

\footnotetext{
${ }^{5}$ A high share of general contents during apprenticeship training can also be derived from low or non-existent wage disadvantages faced by establishment switchers compared with stayers directly after their apprenticeship training (Göggel and Zwick, 2012; Dustmann and Schönberg, 2012).
} 
same point in time (therefore there are no differences in specific labour demand when they start their career as skilled employees).

Seventh, there are specific rules for wage setting for apprentices. Apprentices' wages are usually set by collective bargaining at the sector level according to $\S 17$ of the Vocational Training Act (BBiG). In principle, apprentices in each of the 26 economic sectors defined by collective bargaining should earn the same wage irrespective of their occupation ${ }^{6}$. According to $\S 17 \mathrm{BBiG}$, a firm also has to pay an appropriate wage when not covered by collective bargaining $^{7}$. The Chambers control whether wages in training contracts are within an accepted range. However, there is some leeway for individual wage setting even for employers with collective bargaining: A) enterprises are free to voluntarily pay a wage bonus; B) collective bargaining agreements might include different earnings level options for apprentices; C) wage supplements are possible for especially demanding or dangerous jobs or extra hours.

Taken together, apprentices receive broadly accepted, visible and transparent training certificates at the end of their training period. These skills allow them to accept a skilled job either with their training firm or an outsider firm, and to bargain freely their entry earnings as skilled workers.

\section{Data}

In addition to the institutional framework, an analysis of poaching requires individual data about apprentices who leave the training firm and establishment data about training and raiding firms. This information can be obtained from the IAB linked employer-employee data set longitudinal version 2 (LIAB). The LIAB combines individual employment statistics from social security records with plant-level survey data from the IAB Establishment Panel. The distinctive feature of the LIAB is the combination of administrative information on individuals and details concerning establishments that employ those individuals. The LIAB longitudinal version comprises all establishments with three consecutive entries in the IAB Establishment Panel between 1999 and 2002 and all employees who worked at least one day in those establishments between 1997 and 2003. The data report complete employment histories between 1993 and 2006 (Jacobebbinghaus, 2008).

\footnotetext{
${ }^{6}$ More than two-thirds of apprentices are trained at establishments with collective bargaining and, additionally, $22 \%$ of apprentices work at establishments with wages oriented at collective bargaining (Schönfeld et al., 2010).

${ }^{7} \mathrm{~A}$ wage is appropriate if it is at most 20 per cent below the collective bargaining rate for apprentices (Lakies and Nehls, 2009).
} 
However, in our random sample, most graduates do not move between sampled firms but to firms not included in the sample. Thus, we merge the Establishment History Panel (EHP) using the unique establishment identification number in order to add basic establishment characteristics for the firms to which apprenticeship graduates move. The EHP contains aggregated establishment-level information (such as employee and earnings structure, size and sector $)^{8}$. We use the LIAB to identify poaching and the EHP to identify establishment characteristics of poaching victims and raiding firms.

The LIAB longitudinal data are particularly well suited for our analysis because employment histories are available as spell-data. These spell-data allow a day-based calculation of every recruitment, lay-off, status change (for example from apprentice to skilled worker) and occupation change for every individual. This allows us to distinguish between three and threeand-a-half year apprenticeships based on exam days and training duration. Moreover, we use the two-digit occupation code to identify the training occupation. Thereby, we calculate the exact number of homogeneous apprenticeship graduates at each establishment, occupation and graduation year cluster, and use information about earnings and other individual characteristics of apprenticeship graduates who stayed and left the training firm.

We restrict the data to spells after 1998 because reporting the exact day of transition from apprenticeship to work was not mandatory before 1999 (Jacobebbinghaus, 2008). We use only those apprenticeship graduates with full-time employment in their first jobs after apprenticeship and with regular training duration. A regular training duration begins at the start of a school year (around September) and terminates in the occupation-specific exam week in the first or second quarter of a year. This definition removes drop-outs and examination repeaters from our final sample ${ }^{9}$. Moreover, we drop individuals who earn less than 50 percent or more than 200 per cent of the average in their occupation. Also, we do not include two-year apprenticeships that mostly contain low-level occupations and drop agriculture and non-profit firms. In order to be able to calculate comparison wages between movers and stayers, we only include training firms that have at least two apprentices per occupation and year. This reduces the sample of training firm observations from about 12300 (average establishment size is 288) to about 4300 observations with an average establishment size of 766 .

We identify poaching according to our two indicators at the individual-level and analyse the determinants and consequences of poaching at the establishment-level. We compare firms that

\footnotetext{
${ }^{8}$ The data start on January $1^{\text {st }} 1975$ or establishments' founding date.

${ }^{9}$ Around one-quarter of all apprentices drop out before the final exams.
} 
are victims of poaching with raiding firms and comparable training firms that could avoid poaching in multivariate regressions, in order to reveal systematic differences between the three groups. For the analysis of the causes and consequences of poaching, we show graphs of the development of firm size and the share of newly hired apprentices before and after poaching. Then, we analyse the impact of poaching on the share of newly hired employees and entry earnings of skilled employees in multivariate fixed-effects models. This controls for time-invariant unobservable establishment characteristics. However, we cannot exclude that time-variant unobservable variables such as a change in personnel and training strategy jointly affect downsizing and poaching, so our results on triggers of and responses to poaching may still be biased.

\section{Identification of Poaching}

After describing the institutional framework for identifying firm-sponsored general training in visible and transferable skills and our data set, we proceed with our definition of poaching and discuss the conditions for identifying poaching. Previous studies have used the term "poaching” with a variety of slightly different meanings, but we define it when the following conditions hold: First, the training firm wants to retain an apprenticeship graduate but is not able to keep the best or most productive (“interest to keep”). Instead, the best apprenticeship graduate leaves the training firm to work for a raiding firm. Second, the raiding firm pays the graduate higher earnings than he or she would have received at the training firm ("earnings bonus") ${ }^{10}$.

We stress that our poaching definition focuses on graduates changing employers against the will of training firms. This means that we focus solely on the perspective of the training firm. Usually, apprentices change employers if they receive an outside offer that the training firm cannot counter. However, apprentices also may have personal reasons for wishing to change firm ${ }^{11}$. If the training firm attempts to retain such an apprentice by offering higher earnings at the end of the apprenticeship but the apprentice still leaves, this is an involuntary quit from the training firm's perspective.

\footnotetext{
${ }^{10}$ For the sake of clean identification of poaching, we concentrate on job entrants after apprenticeship training. We therefore exclude a vast area of poaching activities concentrating on experts whose transfer can serve as a mechanism for the acquisition of externally developed knowledge (Song et al., 2003). We assume that learning by hiring (as a means to enter new product markets, acquisition of internally non-existing knowledge or social capital) is only a minor reason for poaching skilled employees at the beginning of their careers.

${ }^{11}$ Cottini et al. (2011) show that an unsupportive boss leads to a 6 percentage point increase in voluntary turnover probability for Danish workers.
} 
We identify poaching by comparing apprenticeship graduates who stay with an employer, with those who switch their employer. We compare stayers with switchers in the same occupation who graduate from the same training firm and work in their training occupation after graduation $^{12}$. In addition, switchers have to find a new job within ten days after graduation $^{13}$. This restricts the sample to larger training firms that have staying (and switching) apprenticeship graduates in the same training occupation in one graduation year (appendix Table B1 summarises shares of staying and switching apprentices).

In detail, the first poaching condition ("interest to keep") states that the switching apprenticeship graduate is more productive than any other staying apprenticeship graduate. It further postulates that the best or most productive apprenticeship graduate is the most desirable job candidate and the training firm wants to keep this candidate. This condition requires a relative productivity assessment between staying and switching apprentices. The first condition includes the possibility that employers plan from the start to retain only a certain fraction of apprenticeship graduates because they screen apprentices during the apprenticeship (Acemoglu and Pischke, 1998; Wagner and Zwick, 2012) ${ }^{14}$.

The second ("earnings bonus") condition states that a switching apprenticeship graduate receive higher earnings at the raiding firm than he or she would get at the training firm. This condition implies that the training firm was unable or unwilling to counter the offer by the raiding firm. According to this condition, it is also possible that the training firm is willing to bid up earnings of the leaving apprenticeship graduate to his or her productivity level but assesses the productivity of the leaving apprenticeship graduate at a lower level than the raiding firm.

In contrast to institutional regulations stating that earnings for all apprentices should be equal, we find striking earnings variations between apprentices in the same training year, in the same occupation and at the same training establishment. The standard deviation of apprentices' earnings at the end of apprenticeship is 0 for only 4.4 per cent of training establishments with at least one moving and one staying apprenticeship graduate. Most training establishments pay their apprentices slightly different earnings, even comparing apprentices with similar

\footnotetext{
${ }^{12}$ We do not consider occupation switchers because occupations differ with respect to average earnings level, reputation and selectivity. We also exclude apprenticeship graduates with an unemployment spell after graduation because that may be a stigma.

${ }^{13}$ These "immediate" employer switchers make up 10 per cent of all apprenticeship graduates in our sample. Moreover, short non-employment spells of switchers are usually interpreted as a sign of quitting rather than firing. Most transitions take place during the first three days.

14 Author (2001) also shows that temporary help firms use training as a screening period and therefore voluntarily let trained employees go.
} 
characteristics. The average dispersion of earnings is 2.03 Euros a day - this difference accounts for around 7 per cent of the daily gross earnings within a firm, occupation and graduation year cell (Table 1$)^{15}$.

We interpret earnings differences between apprentices at the end of their apprenticeship within the same establishment and occupation as relative differences in productivity and therefore the attractiveness of retaining an apprentice. This argument is supported by the fact that earnings variation within an establishment/occupation/graduation year cell triples when the final exam approaches (Appendix: Figure A1). The increase in apprentice earnings variation illustrates that employers monitor apprentice productivity and reward those that are more productive. We collect further arguments for this hypothesis in appendix A of this paper.

The small earnings differences at the end of the apprenticeship training are not visible to outsider firms, only the external researcher. Apprenticeship graduates in one training firm, occupation and graduation year cell are heterogeneous to outsider firms in terms of practical and theoretical exam grades and other individual characteristics such as schooling background or age. This means that certification at the end of apprenticeship allows (potential) raiding firms, at least to a certain extent, to assess differences in quality of apprentices (Acemoglu and Pischke, 2000) ${ }^{16}$.

We find that 33 per cent of immediately moving "best” apprenticeship graduates earn more than the best-paid stayer at the end of the apprenticeship, see Table 2 , column $2^{17}$. In more detail, 24 per cent of all immediate movers in expensive blue-collar manufacturing occupations earn more than those who stayed with the training firm at the end of the apprenticeship. This share is somewhat lower than that for cheaper white-collar occupations (41 per cent) ${ }^{18}$.

\footnotetext{
${ }^{15}$ The average apprentice salary within an establishment/occupation cluster is 28.60 Euros a day.

${ }^{16}$ Information on relative graduate quality in the training firms therefore might be symmetric, because the relevant quality differences are credibly documented by certificates. Schönberg (2007) also shows that employer learning is symmetric in the case of German apprentices.

${ }^{17}$ In order to identify both poaching conditions, we make sure that the poaching and raiding establishments do not simply belong to the same company. Therefore, we analyse employee flow between firms and delete all cases when more than 10 per cent of all out- or inflowing employees switch between a poaching victim and the respective raiding firm. This procedure leads to an exclusion of 10.5 per cent of potential poaching victims.

${ }^{18}$ The high proportions of the best leaving apprentice on all immediate moving apprentices can result from firms' earnings policy to motivate good apprentices to stay (Mohrenweiser and Zwick, 2013). The firm can use higher earnings offers to compensate the disutility of a worker who has preferences to work closer to his or her home, is not satisfied with his or her colleagues, supervisors, career perspectives or work environment (Acemoglu and Pischke, 1998). Indeed, only in 5 per cent of all cases are immediately moving graduates the best-paid apprentices in their occupation/establishment/graduation year cell.
} 
Indeed, the decision by the "best apprentice" to leave a training firm might be a consequence of individual preference and not a superior offer from an outside firm. Therefore, we additionally impose the second condition that raiding firms are willing to offer an earnings bonus for switching apprenticeship graduates. Calculation of earnings bonuses for switching apprenticeship graduates requires counterfactual earnings, that is earnings that a leaving apprenticeship graduate would have received if he or she stayed with the training firm. We construct the counterfactual earnings level as the highest earnings of those apprenticeship graduates in the same cell who stay with the training firm. These earnings are the highest revealed willingness by the training firm to pay for an apprenticeship graduate. Table 3 shows that 30 per cent of all immediate movers indeed earn more than the best-paid staying apprenticeship graduate in their first regular jobs. This proportion is again lower for immediately moving apprenticeship graduates in expensive blue-collar manufacturing occupations (22 per cent) than in white-collar occupations (40 per cent).

The second condition alone is also not sufficient to identify poaching. For example, the "earnings mark-up” condition is also met if the second-best-paid apprentice leaves the training firm and receives an earnings mark-up at the new firm. Here, the training firm may have only planned to hire the best apprentice ("interest to keep” condition) and the secondbest-paid apprentice might just have been lucky with the earnings offer from the outside firm. Therefore, we combine both conditions to identify poaching.

Table 4 shows that for 12.5 per cent of all immediately moving apprenticeship graduates both poaching conditions are met. Moreover, poaching is less frequent in more cost-intensive bluecollar manufacturing occupations (7.3 per cent) than in white-collar occupations (18.5 per cent). This implies that poaching is observable for apprentices at training firms with large investment in training, but is less widespread for these occupations.

\section{Characteristics of Poaching Victim Firms}

As our main interest is to characterise triggers of and responses to poaching, we turn to the establishment-level. Around 3.2 per cent of training firms with at least two apprenticeship graduates in the same training occupation and graduation year are victims of poaching. This number shows that poaching according to our strict definition does exist, but seems not to be widespread in the German apprenticeship system. However, our poaching conditions exclude firms that train only one apprenticeship graduate and firms that have no staying apprenticeship graduate. These firms are generally considered to run a higher risk of poaching. Hence, our number represents a lower bound of poaching. 
For the following analyses, we define three groups of firms: poaching victim, raiding and control firms. Control firms are those firms with at least two apprenticeship graduates in one occupation and graduation year cell that successfully retain the best apprenticeship graduate. Each of the three groups can contain several observations from one establishment ${ }^{19}$, but each group is exclusive. This means that we delete all firms from the control group that suffer poaching in any other year ${ }^{20}$, and we check that raiding firms are never poaching victims or control firms in any other year.

We start our analysis by comparing poaching victims with raiding firms in order to analyse incentives and possibilities for raiding firms to poach apprenticeship graduates. Afterwards, we investigate differences between poaching victims and control firms, and focus on the question of how firms could prevent poaching of their best apprenticeship graduates.

\section{Poaching victims vs. raiding firms}

Table 5 shows descriptive statistics of poaching victims and raiding firms. There are three main differences: First, raiding firms experience employment growth of 4.9 per cent compared with a 2.5 per cent decline within poaching victims during the year before poaching. However, poaching victim firms are still larger than raiding firms. Second, poaching victims train more apprentices as a proportion of all employees (9.7 per cent) than raiding firms (3.9 per cent). Despite the lower proportion of apprentices, 83.2 per cent of raiding firms train apprentices themselves. Third, raiding firms pay higher earnings than poaching victims. This holds for the 25, 50 and 75 per cent earnings quartile for skilled employees. Finally, both groups have a similar employment composition. Also the multivariate Probit regressions shown in Table 6 confirm that poaching victims are larger but shrinking, pay less, and train more than raiders.

We proceed by investigating the development of these characteristics up to three years before and after poaching. Figure 1 illustrates the development of the number of employees. The horizontal axis displays the timing, starting three years before poaching until three years after poaching which occurs at time zero ${ }^{21}$. It shows that poaching victims are smaller than raiding firms three years before poaching. However, raiding firms grow strongly by 20 per cent in the following three years. On the contrary, employment in poaching victims shrinks during the

\footnotetext{
${ }^{19}$ We find, for example, that 78 per cent of poaching victims experience poaching only once, with those remaining experiencing poaching twice.

${ }^{20}$ We identify 369 observations of poaching victims as potential control firms in other years.

${ }^{21}$ The figures display one-time victims only. As most two-time victims suffer poaching in two consecutive years, including those firms does not change the figures qualitatively. The restriction on one-time victims explains small differences in the number of observations in Tables 5 and 6 .
} 
same period by around 4 per cent. At the time of poaching, raiding firms are larger than poaching victims ${ }^{22}$. After poaching, both groups reduce the number of employees. These findings are confirmed in Appendix Table B2, which displays coefficients of being a poaching victim on firm size and employment growth in OLS regressions controlling for further firm characteristics. The difference in the number of employees between raiding firms and poaching victims is insignificant during the seven-year period but employment growth significantly differs between both groups in the years before and when poaching happens.

Figure 2 illustrates the development of the proportion of newly recruited apprentices on all employees for the same period. Poaching victims train two times more apprentices in proportion to all employees, than do raiding firms. This proportion slightly decreases after poaching but remains higher for poaching victims than for raiding firms. Appendix Table B2 analogously shows coefficients of the poaching victim dummy on the share of new training places on all employees controlling for additional establishment characteristics. These regressions confirm significant differences in apprentice intake between poaching victims and raiding firms over the entire observation period. Moreover, poaching does not change training participation for poaching victims - less than 4 per cent of poaching victims quit apprenticeship training altogether in the three years after poaching ${ }^{23}$. In accordance with Cahuc et al. (1990), we also find no substantial reduction in training efforts of raiders before or after the poaching event.

\section{Poaching victims vs. control firms}

We proceed with differences between poaching victims and control firms. Table 5 shows descriptive statistics and Table 7 presents marginal effects after a Probit regression that controls for additional establishment characteristics. Poaching victims differ remarkably from control firms. Poaching victims have more employees (1,627 to 766), train a higher share of apprentices as a proportion of total employment (9.7 to 7.1 per cent) and pay higher earnings (99.11 to 91.61 Euros at median) than control firms. Marginal effects after Probit (Table 7, column 1) show that 10 per cent higher earnings raise the poaching probability by around 1 percentage point. An earnings increase by 10 per cent decreases the poaching probability by

\footnotetext{
${ }^{22}$ The level difference is insignificant, however. The different number of observations compared with Table 5 is again caused by the selection of one-time victims in this exercise. One-time victims are smaller than multiple victims but we cannot define the zero period for multiple victims.

${ }^{23}$ We can only observe the development of wages measured at quartiles in the EHB. The quartiles show a slight decrease of median earnings for raiding firms over the seven-year period and an increase for poaching victims. However, an analysis with the LIAB data for poaching victims shows that earnings increase in the quartiles stems from lay-offs. New recruits and laid-off workers are more likely to be at the bottom of the earnings distribution and this appears to drive our entire findings on earnings quartiles. In this line, the earnings decrease of raiding firms could stem from hiring.
} 
0.07 percentage points. These results can be explained by the workforce reduction of poaching victims, which is more likely to affect employees on the lower part of the earnings distribution (according to the last-in, first-out principle). Furthermore, employing 1,000 more employees increases the poaching probability by only 0.3 percentage points, and an employment reduction of 10 per cent reduces the poaching probability by 0.6 percentage points. Finally, poaching victims employ significantly more apprentices, females and fewer foreign employees.

We investigate more thoroughly the finding that large firms having high earnings are more likely to be poaching victims, and exploit the additional survey information of the IAB establishment panel, which we can merge for a sub-sample of 62.8 per cent of firms. Firms in the sub-sample are similar to those in the entire sample (Table 7, column 2). Additional variables from the establishment survey allow us to control for establishment characteristics such as investments, industrial relations and exports (Table 7, column 3). This regression confirms that competitive firms with higher investments per capita, a higher export-share and with a collective agreement are more likely to be poaching victims.

We now extend the model in column 1 of Table 7 and take into account time-invariant variables that could simultaneously affect poaching and employment reduction, such as leadership culture, management quality, incentive and reward systems or general human resource practices. Therefore, we estimate a Linear Probability First Difference Model, with first differences between the year of poaching and the previous year ${ }^{24}$.

The first two columns of Table 8 show results for all firms, and the last two columns for firms with blue-collar manufacturing apprentices. Taking firm fixed-effects into account reveals additional poaching triggers. The regression in column 2 shows that an employment decrease of 10 per cent significantly increases the probability of being a poaching victim by 0.27 percentage points. Therefore, employment reduction explains around 9 per cent of the overall probability of being a poaching victim. Further control variables are no longer significant.

Our findings also hold if we compare firms that train blue-collar manufacturing apprentices ${ }^{25}$ (compare appendix: Table B3 for descriptive statistics and columns 3 and 4 in Table 8). These occupations are of particular relevance for poaching because firms have to invest more in apprenticeship training in blue-collar manufacturing occupations and therefore have an

\footnotetext{
${ }^{24}$ We use the entire sample as the following regressions also require information in the year before poaching. This is too restrictive for the sub-sample with the merged IAB Establishment data.

${ }^{25}$ We can only compare poaching victims and control firms with regard to differences between white- and bluecollar manufacturing apprentices as we do not have information on the occupation-level for raiding firms.
} 
interest in retaining graduates (Mohrenweiser and Zwick, 2009, Schönfeld et al. 2010). This makes blue-collar manufacturing apprenticeship graduates more valuable than other graduates for training firms and poaching firms alike. In the sub-sample of blue-collar apprentices, employment decrease has a comparable impact on poaching. All other variables remain insignificant.

\section{Firms' response to poaching}

Poaching victims, in principle, have three possible responses to poaching: they can reduce training expenses, improve retention of attractive apprenticeship graduates by increasing earnings of apprentices or skilled entry payments, and/or adjust the number of training places $^{26}$. As we have no establishment-level data on training expenses, our analysis concentrates on the latter two responses.

We continue to analyse differences between poaching victims and control firms. We use the following timing approach: firms suffer poaching or fulfil criteria as a control firm in period 0 and periods 1, 2 and 3 show changes between period 0 and the respective year. We continue to apply fixed-effect models as we are interested in responses or changes in behaviour of poaching victims controlling for time-invariant factors such as leadership culture and HR measures.

Table 9 presents a fixed-effects model detailing the share of newly hired apprentices. The first two columns of Table 9 show estimates for all firms, and the third and fourth columns show estimates for firms that train apprentices in blue-collar manufacturing occupations. Columns 2 and 4 present a richer model, including many establishment characteristics usually associated with the training decision of firms. Apprenticeship training is usually a sign of an internal labour market characterised by long-term personnel contracts and a low turn-over of skilled employees (Moen and Rosen, 2004; Backes-Gellner and Tuor, 2010). Another indicator for internal labour markets is the difference between tenure and experience - a larger difference means that the employer hires employees with relatively long labour market experience rather than developing its own personnel. In addition, training efforts differ by establishment size and the qualification structure of employees as well as the share of female, foreign and older employees. Poaching victims do not adjust numbers of training places in the year after poaching has taken place. However, poaching occurs in spring or summer after the legally fixed termination of apprenticeships, but many firms decide about new intakes up to one year

\footnotetext{
${ }^{26}$ Training firms can also adjust their selection criteria for apprentices and the HRM policy to attract apprenticeship graduates. Both policies are, unfortunately, not observable with our data.
} 
in advance so an immediate response is unlikely. Hence, we expect firms' responses in the following years. In the second year after poaching, poaching victims indeed reduce the share of training places on all employees by 0.4 percentage points ${ }^{27}$, and in the third by 0.6 percentage points compared with the year of poaching. In the year of poaching, the raw share of new apprentice intakes is 3.5 per cent for poaching victims and 2.3 per cent for control firms. Three years after poaching, poaching victims still train a larger share of apprentices than control firms but they slightly reduce their training efforts.

These patterns also hold for firms that train apprentices in blue-collar manufacturing occupations. The share of intakes is similar in the first year after poaching, then decreases by 0.7 percentage points in the second and 1.3 percentage points in the third years. The reduction is twice that of the entire sample.

Furthermore, poaching victims also can increase earnings for apprenticeship graduates in their first job as an attempt to counter raid attempts by outsider firms. Columns 1 and 2 of Table 10 present fixed-effects earnings regressions up to three years after poaching compared with control firms again for parsimonious and richer specifications. Columns 3 and 4 repeat these regressions for firms with blue-collar manufacturing apprentices. Poaching victims do not adjust earnings of apprenticeship graduates in response to poaching. We also find no differences between occupations.

\section{Robustness checks}

We run a series of robustness checks with regard to our definition of poaching: First, we relax our rather strong poaching conditions. Instead of the first condition that "the leaving best apprentice" has to earn more than the best staying apprenticeship graduate, we now request that the leaving apprenticeship graduate has to earn more than the mean within a firm/occupation/graduation year cell at the end of the apprenticeship. Around 50 per cent more apprenticeship graduates who change employer meet the weaker condition. This recalculation leads to 4.2 per cent poaching victims. However, the results on triggers of, and responses to, poaching remain robust.

Second, we test whether our results hold for a more restrictive occupation classification. We run the analysis with the more precise 3-digit occupation code. As a general rule, blue-collar manufacturing or service occupations with the same 2-digit but different 3-digit codes are

\footnotetext{
${ }^{27}$ The decrease in the second year after poaching remains insignificant, however.
} 
usually only different specialisations of similar occupations ${ }^{28}$. Different specialisations could be seen as substitutes for potential raiding firms. A 3-digit code is, therefore, less appropriate for our kind of analysis. However, using a 3-digit code does not change our main results ${ }^{29}$.

\section{Consequences for the labour market}

Our results suggest that poaching is not just a theoretical construct, it does happen even in economies with a high-skill, high-training equilibrium such as Germany ${ }^{30}$. However, the extent of poaching is rather modest, occurring in around 3 per cent of training firms.

We show that poaching victims are in a temporary downturn, whereas raiding firms strongly grow during the years before poaching. As apprenticeship training usually takes at least three years, raiding firms might have been too pessimistic and poaching victims too optimistic about their skilled labour demand when poached apprentices were hired. This argument is supported by the response of poaching victims to poaching - they slightly reduce the share of apprentice intake but they do not increase entry payments of skilled labour market entrants nor quit training participation altogether.

We further find that poaching victims are larger firms that train more apprentices and pay more than comparable firms that manage to keep their best apprentices. High-paying training firms attract apprentices from the upper end of the ability distribution and they are usually considered to be high-quality training firms in “normal” times (Soskice, 1994; Smits, 2006) ${ }^{31}$. Their apprenticeship graduates are seen to be worthwhile poaching prey. Outsider firms may only dare to poach, or may only be successful and able to poach, if a high-quality training firm shows temporary signs of vulnerability. Outsider firms might exploit the current weakness of poaching victims and hire well-trained apprenticeship graduates. This interpretation suits the first poaching condition that poaching victims keep apprenticeship graduates of a cohort but are not able to retain the best graduate. Furthermore, poaching victims do not adjust entry wages of retained apprenticeship graduates in the first skilled job after recovering from economic weakness.

\footnotetext{
${ }^{28}$ This does not hold for crafts occupations. Our sample, however, consists of rather large firms that rarely train apprentices in crafts occupations.

${ }^{29}$ The robustness of earnings estimations regarding the 2-, 3- or 4-digit occupational code for apprentices is also shown by Wydra-Somaggio and Seibert (2010).

${ }^{30}$ See Finegold and Soskice (1988), Acemoglu and Pischke (1999b) or Culpepper (1999) for country differences in training.

${ }^{31}$ School-leavers in poaching victim firms are more likely to be positively selected. Around 27.2 per cent of all apprentices in poaching victim firms have a university entrance diploma compared with 21.1 per cent in control firms $(\mathrm{t}=1.98)$.
} 
These insights are important because they solve a much cited puzzle - how is it possible that a high training equilibrium with investment in apprenticeship training is not put into question by the possibility of poaching? Our answer is that poaching occurs only sporadically and poaching victims are not "typical” victims but high-quality training firms in a temporary economic downturn. They reduce their training efforts after a poaching event but only to the level of comparable firms that did not experience poaching. Therefore, the overall importance of poaching on expected returns to apprenticeship training and firms' training decisions seems to be negligible.

\section{Conclusions}

This paper presents the first empirical evidence of the existence of poaching. It estimates a lower bound of poaching, describes poaching victim and raiding firm characteristics and analyses triggers of, and responses to, poaching. The paper identifies employees a training firm wishes to retain by their relative productivity position in a homogeneous comparison group. We identify relative productivity of apprentices using relative earnings differences between apprentices who perform the same job in the same firm and graduation year. The skilled entry payments of those apprentices who stay in the training firm serves as counterfactual earnings poached employees would have got had they stayed.

We define poaching when two conditions are met. The apprenticeship graduates who change to another employer, first, have to earn a higher wage at the end of the apprenticeship period and, second, have to earn more in the first regular skilled full-time job after graduation than their peers in the same training establishment, occupation and graduation year. The paper shows that at least 3 per cent of the training firms suffer poaching. This share represents a lower bound because our poaching conditions restrict our sample to large firms that are generally considered to be less exposed to poaching than small firms.

Furthermore, we show that poaching victims employ more employees and pay higher earnings than firms that are able to retain their best apprenticeship graduates. Instead, the vulnerability of poaching victims stems from a current economic weakness indicated by a workforce reduction. During a temporary downsize, training firms may not be able to make counteroffers for apprenticeship graduates with attractive outside offers even if they would like to retain them. Moreover, as the high quality of training and initial screening of large and highearnings firms is well-known in local labour markets, outsider firms exploit this current weakness and are willing to pay a lot for well-trained apprenticeship graduates they otherwise would not be able to attract. Finally, poaching victims respond to poaching by slightly 
reducing the share of new apprentice intakes as a proportion of all employees. They do not adjust earnings for apprenticeship graduates in their first jobs as skilled employees, nor do they quit training altogether.

This paper contributes to the empirical training literature by presenting feasible and innovative conditions to empirically identify poaching. It therefore provides an empirical strategy to identify relative productivity differences of apprentices within firms. It confirms theoretical finding of a coexistence of poaching and firm-sponsored training investments and points to a low incidence of poaching in a high training equilibrium country. The current economic difficulties of poaching victims and the small poaching incidence lead us to the conclusion that poaching has no strong influence on firms' training decisions and expected returns to training.

The transfer of our identification strategy of poaching to other training systems in countries with an established dual apprenticeship training system such as Switzerland or Austria or countries without a comparable system such as the Anglo-Saxon countries or Sweden might be interesting. We cannot analyse with our data whether potential poaching or a poaching experience are an important reason for establishments not to train at all. Moreover, our poaching conditions permit only the identification of a lower bound of the extent of poaching and restrict the analysis to large firms. Strategies of small and low-paying firms for handling the poaching threat may differ.

\section{References}

Acemoglu D and Pischke J (1998). Why Do Firms Train? Theory and Evidence, Quarterly Journal of Economics 113(1): 79-119.

Acemoglu D and Pischke J (1999a). The Structure of Wages and Investment in General Training, Journal of Political Economy 107(3): 539-572.

Acemoglu D and Pischke J (1999b). Beyond Becker: training in imperfect labour markets, Economic Journal 109(453): 112-142.

Acemoglu D and Pischke J (2000). Certification of Training and Training Outcomes, European Economic Review 44: 917-927.

Akerlof G (1984). Gift Exchange and Efficiency-Wage Theory: Four Views, American Economic Review 74(2): 79-83.

Author D (2001). Why do Temporary Help Firms Provide Free General Skills Training? Quarterly Journal of Economics 116(4): 1409-1448. 
Backes-Gellner U and Tuor S (2010). Avoiding Labor Shortages by Employer Signaling - On the Importance of Good Work Climate and Labor Relations, Industrial and Labor Relations Review 63(2): 271-286.

Backes-Gellner U and Oswald Y (2012). Learning for a bonus: How financial incentives interact with preferences, Economics of Education Working Paper No. 79, Zurich.

Barron J, Berger M and Black D (1999). Do Workers Pay for On-the-Job Training? Journal of Human Resources 34(2): 235-252.

Barron J, Berger M and Black D (2006). Selective Counteroffers, Journal of Labor Economics 24(3): 385-409.

Bassanini A, Booth A, Brunello G, De Paola M and Leuven E (2007). Workplace Training in Europe, In Brunello G, Garibaldi P and Wasmer E (Eds.), Education and Training in Europe. Oxford: Oxford University Press: 143-309.

Booth A and Zoega G (2004). Is Wage Compression a Necessary Condition for FirmFinanced General Training? Oxford Economic Papers 56(1): 88-97.

Booth A and Bryan M (2005). Testing Some Predictions of Human Capital Theory: New Training Evidence from Britain, Review of Economics and Statistics 87(2): 391-394.

Brunello G and De Paola M (2009). Is There Under-Provision of Training?, Empirical Research in Vocational Education and Training 1(1): 1-18.

Cahuc P, Sevestre P and Zajdela H (1990). Négociations salariales et segmentation du marché du travail, Economie et prevision 92-93: 43-50.

Cottini E, Kato T and Westergaard-Nielsen N (2011). Adverse workplace conditions, highinvolvement work practices and labor turnover: Evidence from Danish linked employer-employee data, Labour Economics 18(6): 872-880.

Culpepper P (1999). The Future of the High-Skill Equilibrium in Germany, Oxford Review of Economic Policy 15(1): 43-59.

Combes PP and Duranton G (2006). Labour pooling, labour poaching, and spatial clustering, in Regional Science and Urban Economics 36(1): 1-28

Dustmann C and Schönberg U (2012). What makes Firm-based Vocational Training Schemes Successful? The Role of Commitment, American Economic Journal: Applied Economics 4(2): 36-61.

Farber H and Gibbons R (1986). Learning and Wage Dynamics, Quarterly Journal of Economics 111(4): 1007-1047.

Finegold D and Soskice D (1988). The Failure of Training in Britain: Analysis and Prescription, Oxford Review of Economic Policy 4(3): 21-53.

Flinn C (1986). Wages and Job Mobility of Young Workers, Journal of Political Economy 94(3):S88-S110. 
Göggel K and Zwick T (2012). Heterogeneous Wage Effects of Apprenticeship Training, Scandinavian Journal of Economics 114 (3): 756 - 779.

Jacobebbinghaus P (2008). LIAB-Datenhandbuch, Version 3.0.FDZ Datenreport 03/2008.

Kahn L (2013). Asymmetric Information between Employers. IZA Discussion Paper 7147, Bonn.

Kampkötter P and Sliwka D (2011). Wage Premia for Newly Hired Employees: Theory and Evidence, IZA Discussion Paper 5538, Bonn.

Lakies T and Nehls H (2009). Berufsbildungsgesetz. Basiskommentar, Frankfurt/M: BundVerlag.

Lazear EP (1986). Raids and Offer-Matching, Research in Labor Economics, 8(A): 141-165.

Lazear EP (2009). Firm-Specific Human Capital: A Skill-Weights Approach, Journal of Political Economy 117(5): 914-940.

Leuven E (2005). The Economics of Private Sector Training: A Survey of the Literature, Journal of Economic Surveys 19(1): 91-111.

Loewenstein M and Spletzer J (1999). General and Specific Training: Evidence and Implications, Journal of Human Resources 34(4): 710-733.

Moen E and Rosen A (2004). Does Poaching Distort Training? Review of Economic Studies 71(4): 1143-1162.

Mohrenweiser J and Zwick T (2009). Why Do Firms Train Apprentices? The Net Cost Puzzle Reconsidered, Labour Economics 16(6): 631-637.

Mohrenweiser J and Zwick T (2013). Gift exchange and loyalty, mimeo.

Mühlemann S and Wolter SC (2011). Firm-sponsored training and poaching externalities in regional labor markets, in Regional Science and Urban Economics 41(6): 560-570.

Parrotta P and Pozzoli D (2012). Learning by Hiring and Productivity: The Case of Denmark, RAND Journal of Economics 43(1): 167-185.

Picchio M and van Ours JC (2011). Market imperfections and firm-sponsored training, Labour Economics 18(5): 712-722.

Pischke J (2007). Comments on "Workplace Training in Europe”, in Brunello G, Garibaldi P and Wasmer E (Eds.) Education and Training in Europe (pp. 330-342): Oxford University Press.

Postel-Vinay F and Robin J-M (2004).To Match or not to Match? Optimal Wage Policy with endogenous worker search intensity, Review of Economic Dynamics 7(2): 297-330.

Ryan P, Wagner K, Teuber S and Backes-Gellner U (2013). Trainee Pay in Britain, Germany and Switzerland: Institutions, Market Forces, Market Power, European Journal of Industrial Relations (forthcoming). 
Ryan P (2011). Apprenticeship: Between Theory and Practice, School and Workplace, Economics of Education Working Paper No. 64, Zurich.

Sadowski D (1980). Berufliche Bildung und betriebliches Bildungsbudget zur ökonomischen Theorie der Personalbeschaffungs- und Bildungsplanung im Unternehmen. Stuttgart: Poeschel Verlag.

Schönberg U (2007). Testing for asymmetric employer learning, Journal of Labor Economics 25 (4): 651-692.

Schoenfeld G, Wenzelmann F, Dionisus R, Pfeifer H and Walden G (2010). Kosten und Nutzen der dualen Ausbildung aus Sicht der Betriebe. Bielefeld: Bertelsmann Verlag.

Smits W (2006). The Quality of Apprenticeship Training, Education Economics, 14(3): 329344.

Song J, Almeida P and Wu G (2003). Learning-by-Hiring: When is Mobility More Likely to Facilitate Interfirm Knowledge Transfer? Management Science 49(4): 351-365.

Soskice D (1994). Reconciling Markets and Institutions: The German Apprenticeship System, In Lynch LM (Ed.), Training and the Private Sector: International Comparisons, Chicago: University of Chicago Press: 26-60.

Stevens M (1994). A theoretical model of on-the-job training with imperfect competition, Oxford Economic Papers 46(4): 537-562.

Stevens M (1996). Transferable Training and Poaching Externalities, In Booth A and Snower D (Eds.), Acquiring Skills - Market Failures, Their Symptoms and Policy Responses (pp. 19-37): Cambridge University Press.

Stevens M (2001). Should Firms Be Required to Pay for Vocational Training? Economic Journal 111(473): 485-505.

Wagner R and Zwick T (2012). How Acid are Lemons? Adverse Selection and Signalling for Skilled Labour Market Entrants, Leading House Working Paper 71, Zurich.

Wydra-Somaggio G and Seibert H (2010). Signalwirkung von Lehrabschlüssen Einkommensunterschiede von Ausbildungsabsolventen beim Berufseinstieg, Sozialer Fortschritt 59(12): 296-305. 
Table 1: Earnings dispersion of apprenticeship graduates at the end of the apprenticeship within establishment/occupation/year cells.

\begin{tabular}{|l|c|}
\hline Standard deviation & 2.03 \\
\hline Mean & 28.60 \\
\hline Minimum & 25.79 \\
\hline Maximum & 31.89 \\
\hline
\end{tabular}

Daily earnings in Euros. Sample restrictions: at least two (one moving and one staying) apprenticeship graduates in each establishment/occupation/year cell. $\mathrm{N}=26,609$. The mover finds his or her new job in the training occupation within 10 days after apprenticeship termination. Source: own calculations of the LIAB longitudinal version 2 1999-2003.

Table 2: Proportion of best apprenticeship graduates who leave the training firm.

\begin{tabular}{|l|c|}
\hline Occupation & Proportion \\
\hline Blue-collar manufacturing & 0.242 \\
\hline White-collar & 0.413 \\
\hline Total & 0.339 \\
\hline
\end{tabular}

Apprenticeship graduates who earn more than the staying apprenticeship graduates within an occupation/establishment cell at the end of the apprenticeship as a proportion of all immediate movers. Sample restrictions: at least two (one moving and one staying) apprenticeship graduates in each occupation/establishment cell. $\mathrm{N}=2,465$. The mover finds his or her new job in the training occupation within 10 days after apprenticeship termination. Source: own calculations on the basis of the LIAB longitudinal version 2 1999-2003. 
Table 3: Proportion of immediately switching apprenticeship graduates who receive an earnings mark-up.

\begin{tabular}{|l|c|}
\hline Occupation & Proportion \\
\hline Blue-collar manufacturing & 0.225 \\
\hline White-collar & 0.403 \\
\hline Total & 0.302 \\
\hline
\end{tabular}

Apprenticeship graduates who earn more than all the staying apprenticeship graduates within an occupation/establishment cell at first full-time employment as a proportion of all immediate movers. Sample restrictions: at least two (one moving and one staying) apprenticeship graduates in each occupation/establishment cell. $\mathrm{N}=2,465$. The mover finds his or her new job in the training occupation within 10 days after apprenticeship termination. Source: own calculations on the basis of the LIAB longitudinal version 2 1999-2003.

Table 4: Proportions of poached apprenticeship graduates by occupation group.

\begin{tabular}{|l|c|}
\hline Occupation group & Proportion \\
\hline Blue-collar manufacturing & 0.073 \\
\hline White-collar & 0.185 \\
\hline Total & 0.125 \\
\hline
\end{tabular}

Proportion of poached apprenticeship graduates who receive higher earnings at the end of the apprenticeship and higher earnings at their first employment as a skilled worker than the staying apprenticeship graduates in the training firm. Sample restrictions: at least two (one moving and one staying) apprenticeship graduates in each occupation/ establishment cell. $\mathrm{N}=2465$. The mover finds his or her new job in the training occupation within 10 days after apprenticeship termination. Source: own calculations on the basis of the LIAB longitudinal version 2 1999-2003. 
Table 5: Descriptive characteristics of poaching victims, raiding firms and control group establishments.

\begin{tabular}{|c|c|c|c|}
\hline & $\begin{array}{c}\text { Poaching } \\
\text { victim }\end{array}$ & Raiding firm & Control group \\
\hline First quartile earnings for skilled workers & $\begin{array}{c}86.41 \\
(16.43)\end{array}$ & $\begin{array}{c}88.61 \\
(14.97)\end{array}$ & $\begin{array}{c}80.58 \\
(17.94)\end{array}$ \\
\hline $\begin{array}{l}\text { Median earnings for skilled employees } \\
\text { (daily earnings) }\end{array}$ & $\begin{array}{c}99.14 \\
(19.67)\end{array}$ & $\begin{array}{l}101.91 \\
(17.85)\end{array}$ & $\begin{array}{c}91.61 \\
(21.53)\end{array}$ \\
\hline $\begin{array}{l}\text { Third quartile earnings for skilled } \\
\text { employees } \\
\text { (daily earnings) }\end{array}$ & $\begin{array}{l}115.65 \\
(24.34)\end{array}$ & $\begin{array}{l}118.69 \\
(22.73)\end{array}$ & $\begin{array}{l}107.36 \\
(26.91)\end{array}$ \\
\hline Number of employees & $\begin{array}{l}1,627 \\
(329)\end{array}$ & $\begin{array}{l}1,277 \\
(2642)\end{array}$ & $\begin{array}{c}766 \\
(1431)\end{array}$ \\
\hline $\begin{array}{l}\text { Employee growth to previous year } \\
\text { in per cent }\end{array}$ & $\begin{array}{l}-0.025 \\
(0.12)\end{array}$ & $\begin{array}{l}0.049 \\
(0.12)\end{array}$ & $\begin{array}{l}-0.001 \\
(0.11)\end{array}$ \\
\hline Churning of skilled employees & $\begin{array}{l}0.271 \\
(0.22) \\
\end{array}$ & $\begin{array}{l}0.251 \\
(0.22) \\
\end{array}$ & $\begin{array}{l}0.325 \\
(0.25) \\
\end{array}$ \\
\hline Share of apprentices & $\begin{array}{l}0.097 \\
(0.08)\end{array}$ & $\begin{array}{l}0.039 \\
(0.05)\end{array}$ & $\begin{array}{l}0.071 \\
(0.05)\end{array}$ \\
\hline Share of female employees & $\begin{array}{l}0.465 \\
(0.27)\end{array}$ & $\begin{array}{l}0.431 \\
(0.29)\end{array}$ & $\begin{array}{l}0.338 \\
(0.25)\end{array}$ \\
\hline Share of foreign employees & $\begin{array}{l}0.045 \\
(0.05) \\
\end{array}$ & $\begin{array}{l}0.063 \\
(0.06) \\
\end{array}$ & $\begin{array}{l}0.056 \\
(0.08) \\
\end{array}$ \\
\hline Share of part-time employees & $\begin{array}{l}0.127 \\
(0.12)\end{array}$ & $\begin{array}{l}0.121 \\
(0.11)\end{array}$ & $\begin{array}{l}0.087 \\
(0.12)\end{array}$ \\
\hline Share of skilled employees & $\begin{array}{l}0.704 \\
(0.13)\end{array}$ & $\begin{array}{l}0.722 \\
(0.16)\end{array}$ & $\begin{array}{l}0.710 \\
(0.16)\end{array}$ \\
\hline Share of high-skilled employees & $\begin{array}{l}0.118 \\
(0.09)\end{array}$ & $\begin{array}{l}0.115 \\
(0.09)\end{array}$ & $\begin{array}{l}0.090 \\
(0.10)\end{array}$ \\
\hline $\begin{array}{l}\text { Number of observations } \\
\text { Number of establishments }\end{array}$ & $\begin{array}{l}147 \\
115\end{array}$ & $\begin{array}{l}159 \\
137\end{array}$ & $\begin{array}{l}4309 \\
1599\end{array}$ \\
\hline
\end{tabular}

Mean, and standard deviation in parenthesis; identification of groups based on the longitudinal version 2 of the LIAB, source: EHB 1999-2003. 
Table 6: Characteristics of poaching victims in comparison with raiding firms.

\begin{tabular}{|l|c|c|c|}
\hline & $(1)$ & $(2)$ & $(3)$ \\
\hline $\begin{array}{l}\text { First quartile earnings for skilled } \\
\text { employees }\end{array}$ & -0.007 & & \\
\hline Median earnings for skilled employees & $(2.29)$ & & \\
\hline Third quartile earnings for skilled & & -0.005 & $(2.07)$ \\
employees & & & -0.004 \\
\hline Earnings growth to previous year & 0.626 & 0.617 & -0.710 \\
& $(0.97)$ & $(0.61)$ & $(0.95)$ \\
\hline Number of employees/1,000 & 0.028 & 0.028 & 0.026 \\
& $(2.28)$ & $(2.28)$ & $(2.13)$ \\
\hline Employee growth to previous year & -1.879 & -1.875 & -1.933 \\
& $(5.26)$ & $(5.30)$ & $(5.35)$ \\
\hline Churning of skilled employees & 0.171 & 0.174 & 0.180 \\
& $(0.98)$ & $(0.99)$ & $(1.01)$ \\
\hline Share of apprentices & 5.646 & 5.549 & 5.654 \\
& $(5.86)$ & $(5.80)$ & $(5.82)$ \\
\hline Share of female employees & 0.035 & 0.092 & 0.132 \\
& $(0.13)$ & $(0.35)$ & $(0.50)$ \\
\hline Share of foreign employees & -1.562 & -1.561 & -1.589 \\
& $(2.22)$ & $(2.20)$ & $(2.25)$ \\
\hline Share of part-time employees & 0.254 & 0.221 & 0.219 \\
& $(0.59)$ & $(0.51)$ & $(0.50)$ \\
\hline Share of skilled employees & -0.295 & -0.310 & -0.313 \\
& $(0.96)$ & $(1.01)$ & $(1.00)$ \\
\hline Share of high-skilled employees & 0.107 & 0.103 & 0.101 \\
& $(0.23)$ & $(0.22)$ & $(0.22)$ \\
\hline Sector and year dummies & Yes & Yes & Yes \\
\hline Number of observations & 306 & 306 & 306 \\
Number of establishments & 252 & 252 & 252 \\
\hline Pseudo R square & 0.32 & 0.31 & 0.31 \\
\hline
\end{tabular}

Marginal effects after Probit. Dependent variable: firm was poaching victim (1) and raiding firm (0). Marginal effects calculated at the mean, standard errors clustered on establishment, z-values in parenthesis. Identification of groups based on the longitudinal version 2 of the LIAB, source: EHB 1999-2003. 
Table 7: Characteristics of poaching victims in comparison with control firms.

\begin{tabular}{|c|c|c|c|}
\hline & (1) & $(2)$ & (3) \\
\hline $\begin{array}{l}\text { Median earnings for skilled } \\
\text { employees }\end{array}$ & $\begin{array}{l}0.001 \\
(5.05)\end{array}$ & $\begin{array}{l}0.001 \\
(7.19)\end{array}$ & $\begin{array}{l}0.001 \\
(6.37)\end{array}$ \\
\hline Earnings growth to previous year & $\begin{array}{l}-0.076 \\
(2.02)\end{array}$ & $\begin{array}{l}-0.066 \\
(2.24)\end{array}$ & $\begin{array}{l}-0.053 \\
(2.25)\end{array}$ \\
\hline Number of employees/1,000 & $\begin{array}{l}0.003 \\
(4.77)\end{array}$ & $\begin{array}{l}0.002 \\
(5.16)\end{array}$ & $\begin{array}{l}0.001 \\
(3.04)\end{array}$ \\
\hline Employee growth to previous year & $\begin{array}{l}-0.063 \\
(3.05)\end{array}$ & $\begin{array}{l}-0.051 \\
(2.95)\end{array}$ & $\begin{array}{l}-0.040 \\
(2.94)\end{array}$ \\
\hline Churning of skilled employees & $\begin{array}{l}-0.017 \\
(1.86)\end{array}$ & $\begin{array}{l}-0.012 \\
(1.69)\end{array}$ & $\begin{array}{r}-0.009 \\
(1.57)\end{array}$ \\
\hline Share of apprentices & $\begin{array}{l}0.191 \\
(6.06)\end{array}$ & $\begin{array}{l}0.148 \\
(5.95)\end{array}$ & $\begin{array}{l}0.140 \\
(6.27)\end{array}$ \\
\hline Share of female employees & $\begin{array}{l}0.044 \\
(2.96)\end{array}$ & $\begin{array}{l}0.036 \\
(3.02)\end{array}$ & $\begin{array}{l}0.034 \\
(3.59)\end{array}$ \\
\hline Share of foreign employees & $\begin{array}{l}-0.057 \\
(1.70)\end{array}$ & $\begin{array}{l}-0.062 \\
(2.39)\end{array}$ & $\begin{array}{l}-0.055 \\
(2.62)\end{array}$ \\
\hline Share of part-time employees & $\begin{array}{l}0.004 \\
(0.18)\end{array}$ & $\begin{array}{l}-0.014 \\
(0.74)\end{array}$ & $\begin{array}{l}-0.014 \\
(0.91)\end{array}$ \\
\hline Share of skilled employees & $\begin{array}{l}0.008 \\
(0.51)\end{array}$ & $\begin{array}{l}-0.005 \\
(0.45)\end{array}$ & $\begin{array}{l}-0.007 \\
(0.71)\end{array}$ \\
\hline Share of high-skilled employees & $\begin{array}{l}0.014 \\
(0.68)\end{array}$ & $\begin{array}{l}0.010 \\
(0.58)\end{array}$ & $\begin{array}{l}-0.008 \\
(0.54)\end{array}$ \\
\hline Positive business expectations & & & $\begin{array}{l}0.001 \\
(0.37) \\
\end{array}$ \\
\hline Ln(investments) & & & $\begin{array}{l}0.001 \\
(1.70)\end{array}$ \\
\hline Export share on sales & & & $\begin{array}{l}0.001 \\
(2.18)\end{array}$ \\
\hline Works council & & & $\begin{array}{l}0.001 \\
(0.12)\end{array}$ \\
\hline Collective agreement & & & $\begin{array}{l}0.011 \\
(2.99)\end{array}$ \\
\hline Payment above collective agreement & & & $\begin{array}{r}-0.005 \\
(1.83)\end{array}$ \\
\hline Sector and year dummies & Yes & Yes & Yes \\
\hline $\begin{array}{l}\text { Number of observations } \\
\text { Number of establishments }\end{array}$ & $\begin{array}{l}4456 \\
1714\end{array}$ & 2980 & 2980 \\
\hline Pseudo $\mathrm{R}^{2}$ & 0.17 & 0.24 & 0.27 \\
\hline
\end{tabular}

Marginal effects after Probit, dependent variable: 1 if firm was poaching victim, 0 if control group. Standard errors clustered on establishment, z-values in parenthesis. Identification based on the longitudinal version 2 of the LIAB, source: EHB 1999-2003. 
Table 8: Causes of poaching: poaching victims in comparison with control group.

\begin{tabular}{|c|c|c|c|c|}
\hline & \multicolumn{2}{|c|}{ All firms } & \multicolumn{2}{|c|}{$\begin{array}{l}\text { Firms with blue-collar } \\
\text { apprentices }\end{array}$} \\
\hline Log(number of employees) & $\begin{array}{l}-0.026 \\
(1.94)\end{array}$ & $\begin{array}{l}-0.027 \\
(1.96)\end{array}$ & $\begin{array}{l}-0.034 \\
(1.99)\end{array}$ & $\begin{array}{l}-0.034 \\
(1.94)\end{array}$ \\
\hline $\begin{array}{l}\text { Median earnings for skilled } \\
\text { employees } / 1,000\end{array}$ & $\begin{array}{l}-0.015 \\
(0.34)\end{array}$ & $\begin{array}{l}-0.015 \\
(0.34)\end{array}$ & $\begin{array}{l}-0.014 \\
(0.24)\end{array}$ & $\begin{array}{l}-0.010 \\
(0.17)\end{array}$ \\
\hline Churning of skilled employees & & $\begin{array}{l}-0.014 \\
(1.91)\end{array}$ & & $\begin{array}{l}-0.001 \\
(0.70)\end{array}$ \\
\hline \begin{tabular}{|l|} 
Share of skilled employees \\
\end{tabular} & & $\begin{array}{l}-0.032 \\
(0.61)\end{array}$ & & $\begin{array}{l}-0.107 \\
(1.48)\end{array}$ \\
\hline Share of part-time employees & & $\begin{array}{c}-0.022 \\
(0.27)\end{array}$ & & $\begin{array}{l}-0.078 \\
(0.60)\end{array}$ \\
\hline $\begin{array}{l}\text { Share of employees older than } \\
55\end{array}$ & & $\begin{array}{l}0.034 \\
(0.38) \\
\end{array}$ & & $\begin{array}{l}0.042 \\
(0.37)\end{array}$ \\
\hline Share of foreign employees & & $\begin{array}{l}0.044 \\
(0.32) \\
\end{array}$ & & $\begin{array}{l}-0.081 \\
(0.49) \\
\end{array}$ \\
\hline \begin{tabular}{|l|} 
Share of female employees \\
\end{tabular} & & $\begin{array}{l}0.151 \\
(1.64) \\
\end{array}$ & & $\begin{array}{l}0.196 \\
(1.49) \\
\end{array}$ \\
\hline Sector and year dummies & & Yes & & Yes \\
\hline Number of observations & 6570 & 6570 & 4202 & 4202 \\
\hline Number of groups & 1714 & 1714 & 734 & 734 \\
\hline within $\mathrm{R}^{2}$ & 0.01 & 0.01 & 0.01 & 0.01 \\
\hline Prob $\left(\mathrm{u} \_\mathrm{i}==0\right)$ & 0.00 & 0.00 & 0.00 & 0.00 \\
\hline
\end{tabular}

Linear probability first difference regressions, dependent variable: 1 poaching victim, 0 control group (interacted with the time effect). Sample restriction: all firms of control group and poaching victims if they have not suffered poaching in the previous year, standard errors clustered on establishment, $t$-values in parenthesis. Source: LIAB longitudinal version 2 1999-2003. 
Table 9: Establishments’ responses to poaching: the share of newly hired apprentices.

\begin{tabular}{|c|c|c|c|c|}
\hline & \multicolumn{2}{|c|}{ All firms } & \multicolumn{2}{|c|}{$\begin{array}{c}\text { Firms with blue-collar } \\
\text { apprentices }\end{array}$} \\
\hline Poaching victim $(\mathrm{t}+1)$ & $\begin{array}{l}0.0002 \\
(0.07)\end{array}$ & $\begin{array}{l}0.0003 \\
(0.11)\end{array}$ & $\begin{array}{l}-0.005 \\
(1.35)\end{array}$ & $\begin{array}{l}-0.005 \\
(1.40)\end{array}$ \\
\hline Poaching victim $(\mathrm{t}+2)$ & $\begin{array}{l}-0.004 \\
(1.60)\end{array}$ & $\begin{array}{r}-0.004 \\
(1.52)\end{array}$ & $\begin{array}{l}-0.007 \\
(1.93)\end{array}$ & $\begin{array}{l}-0.007 \\
(1.85)\end{array}$ \\
\hline Poaching victim $(\mathrm{t}+3)$ & $\begin{array}{l}-0.007 \\
(2.70)\end{array}$ & $\begin{array}{l}-0.006 \\
(2.57)\end{array}$ & $\begin{array}{l}-0.013 \\
(3.52)\end{array}$ & $\begin{array}{l}-0.013 \\
(3.44)\end{array}$ \\
\hline Ln(number of employees) & & $\begin{array}{l}0.002 \\
(3.83)\end{array}$ & & $\begin{array}{l}0.001 \\
(1.69)\end{array}$ \\
\hline $\begin{array}{l}\text { Churning of skilled } \\
\text { employees }\end{array}$ & & $\begin{array}{l}-0.003 \\
(4.38)\end{array}$ & & $\begin{array}{l}-0.004 \\
(4.13)\end{array}$ \\
\hline $\begin{array}{l}\text { Average tenure of skilled } \\
\text { employees } / 1,000\end{array}$ & & $\begin{array}{l}0.002 \\
(2.76)\end{array}$ & & $\begin{array}{l}0.002 \\
(2.08)\end{array}$ \\
\hline $\begin{array}{l}\text { Average difference between } \\
\text { experience and tenure of } \\
\text { skilled employees } / 1,000\end{array}$ & & $\begin{array}{l}0.002 \\
(1.79)\end{array}$ & & $\begin{array}{l}0.003 \\
(2.33)\end{array}$ \\
\hline Share of skilled employees & & $\begin{array}{l}-0.019 \\
(3.88)\end{array}$ & & $\begin{array}{l}-0.018 \\
(2.86)\end{array}$ \\
\hline $\begin{array}{l}\text { Share of part-time } \\
\text { employees }\end{array}$ & & $\begin{array}{l}-0.023 \\
(3.43)\end{array}$ & & $\begin{array}{l}-0.001 \\
(0.11)\end{array}$ \\
\hline $\begin{array}{l}\text { Share of employees older } \\
\text { than } 55\end{array}$ & & $\begin{array}{l}-0.008 \\
(1.26)\end{array}$ & & $\begin{array}{l}-0.025 \\
(3.94)\end{array}$ \\
\hline Share of foreign employees & & $\begin{array}{l}-0.031 \\
(2.24)\end{array}$ & & $\begin{array}{l}-0.047 \\
(2.86)\end{array}$ \\
\hline Share of female employees & & $\begin{array}{l}0.001 \\
(0.18)\end{array}$ & & $\begin{array}{l}-0.011 \\
(1.84)\end{array}$ \\
\hline $\begin{array}{l}\text { Number of observation } \\
\text { Number of groups }\end{array}$ & $\begin{array}{l}9881 \\
1714\end{array}$ & $\begin{array}{l}9881 \\
1714\end{array}$ & $\begin{array}{c}4722 \\
888\end{array}$ & $\begin{array}{c}4722 \\
888\end{array}$ \\
\hline Within $\mathrm{R}^{2}$ & 0.25 & 0.26 & 0.30 & 0.31 \\
\hline Prob (u_i $==0)$ & 0.00 & 0.00 & 0.00 & 0.00 \\
\hline
\end{tabular}

Fixed effects regressions, dependent variable: share of newly recruited apprentices on all employees. Sample restriction: all firms of control group and poaching victims if no poaching occurs in the following years, standard errors clustered on establishment, t-values in parenthesis. Source: LIAB longitudinal version 2 1999-2003. 
Table 10: Establishments' responses to poaching: earnings of apprenticeship graduates in their first job.

\begin{tabular}{|c|c|c|c|c|}
\hline & \multicolumn{2}{|c|}{ All firms } & \multicolumn{2}{|c|}{$\begin{array}{c}\text { Firms with blue-collar } \\
\text { apprentices }\end{array}$} \\
\hline Poaching victim (t+1) & $\begin{array}{l}0.0005 \\
(0.03)\end{array}$ & $\begin{array}{l}0.001 \\
(0.06)\end{array}$ & $\begin{array}{l}-0.025 \\
(0.94)\end{array}$ & $\begin{array}{l}-0.025 \\
(0.93)\end{array}$ \\
\hline Poaching victim $(\mathrm{t}+2)$ & $\begin{array}{l}-0.003 \\
(0.19)\end{array}$ & $\begin{array}{l}-0.003 \\
(0.17)\end{array}$ & $\begin{array}{l}-0.025 \\
(0.95)\end{array}$ & $\begin{array}{l}-0.026 \\
(1.01)\end{array}$ \\
\hline Poaching victim (t+3) & $\begin{array}{l}0.012 \\
(0.72)\end{array}$ & $\begin{array}{l}0.015 \\
(0.90)\end{array}$ & $\begin{array}{l}0.023 \\
(0.85)\end{array}$ & $\begin{array}{l}0.022 \\
(0.82)\end{array}$ \\
\hline Ln(number of employees) & & $\begin{array}{l}0.036 \\
(3.91)\end{array}$ & & $\begin{array}{l}-0.0001 \\
(0.00)\end{array}$ \\
\hline $\begin{array}{l}\text { Churning of skilled } \\
\text { employees }\end{array}$ & & $\begin{array}{l}-0.009 \\
(1.89)\end{array}$ & & $\begin{array}{l}-0.008 \\
(1.27)\end{array}$ \\
\hline $\begin{array}{l}\text { Average tenure of skilled } \\
\text { employees } 1,000\end{array}$ & & $\begin{array}{l}-0.019 \\
(3.28)\end{array}$ & & $\begin{array}{l}-0.023 \\
(3.06)\end{array}$ \\
\hline $\begin{array}{l}\text { Average difference between } \\
\text { experience and tenure of } \\
\text { skilled employees/ } 1,000\end{array}$ & & $\begin{array}{l}0.013 \\
(1.75)\end{array}$ & & $\begin{array}{c}-0.008 \\
(0.84)\end{array}$ \\
\hline Share of skilled employees & & $\begin{array}{l}0.016 \\
(0.39)\end{array}$ & & $\begin{array}{l}-0.107 \\
(1.84) \\
\end{array}$ \\
\hline $\begin{array}{l}\text { Share of part-time } \\
\text { employees }\end{array}$ & & $\begin{array}{l}0.018 \\
(0.37)\end{array}$ & & $\begin{array}{l}-0.056 \\
(0.72)\end{array}$ \\
\hline $\begin{array}{l}\text { Share of employees older } \\
\text { than } 55\end{array}$ & & $\begin{array}{l}-0.0001 \\
(0.02)\end{array}$ & & $\begin{array}{l}-0.003 \\
(0.04)\end{array}$ \\
\hline Share of foreign employees & & $\begin{array}{l}-0.017 \\
(0.15)\end{array}$ & & $\begin{array}{l}-0.156 \\
(1.01)\end{array}$ \\
\hline Share of female employees & & $\begin{array}{l}-0.180 \\
(2.76)\end{array}$ & & $\begin{array}{l}-0.055 \\
(0.59)\end{array}$ \\
\hline $\begin{array}{l}\text { Number of observation } \\
\text { Number of groups }\end{array}$ & $\begin{array}{l}8148 \\
1709\end{array}$ & $\begin{array}{l}8148 \\
1688\end{array}$ & $\begin{array}{c}4076 \\
796\end{array}$ & $\begin{array}{c}4076 \\
796\end{array}$ \\
\hline Within $\mathrm{R}^{2}$ & 0.01 & 0.01 & 0.004 & 0.01 \\
\hline Prob (u_i $==0)$ & 0.00 & 0.00 & 0.00 & 0.00 \\
\hline
\end{tabular}

Fixed effects regressions, dependent variable: log earnings deviation of newly recruited apprentices to occupation median. Sample restriction: all firms of control group and poaching victims if their observation in the following years was not poaching again, standard errors clustered on establishment, t-values in parenthesis. Source: LIAB longitudinal version 2 1999-2003. 
Figure 1: Development of the firm size before and after poaching incidence (period 0).

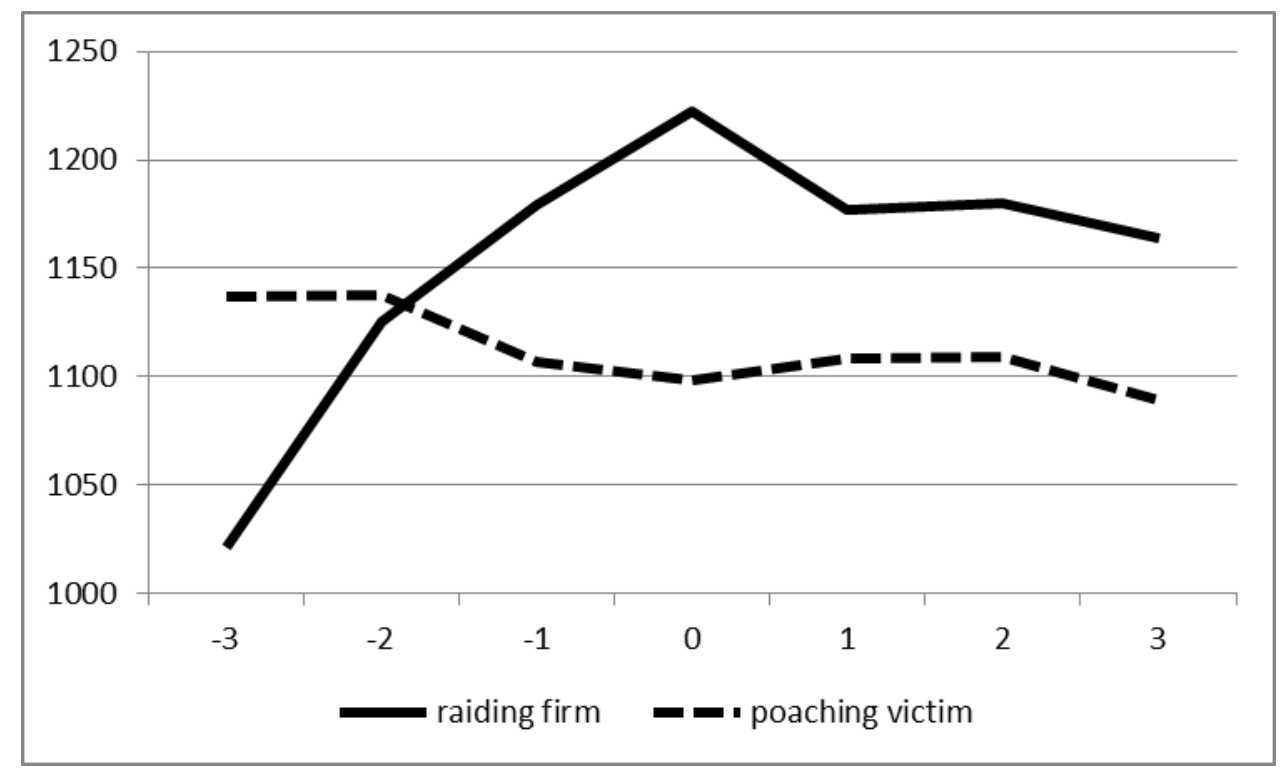

$\mathrm{N}=94$ poaching victims and $\mathrm{N}=121$ raiding firms, only one-time raiding firms and one-time poaching victims. Identification of poaching based on the longitudinal version 2 of the LIAB, source: EHB 1999-2003.

Figure 2: Development of the proportion of newly recruited apprentices before and after poaching incidence (period 0 ).

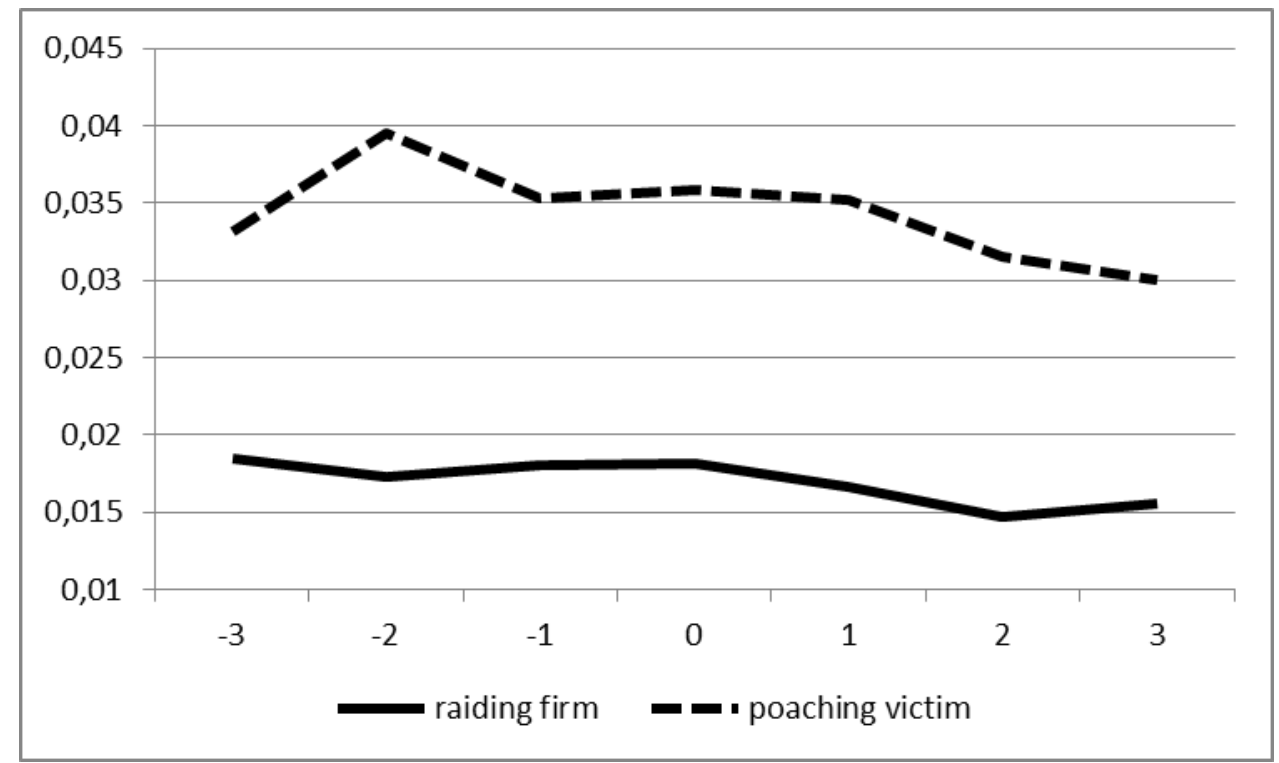

$\mathrm{N}=94$ poaching victims and $\mathrm{N}=121$ raiding firms, only firms that poach only once or were only one-time poaching victims. Identification of poaching based on the longitudinal version 2 of the LIAB, source: EHB 1999-2003. 


\section{Appendix A}

\section{Validation for the interpretation of relative earnings differences as relative productivity differences within an establishment/occupation/year cell}

In this section, we present a couple of justifications for our hypothesis that the relative earnings rank in an establishment/ occupation/ graduation year cell is a sufficient predictor for relative productivity of apprentices in this cell. First, we show that firms are more likely to retain apprenticeship graduates with a high earnings position in a cell, and, second, that earnings deviation at the end of the apprenticeship explains earnings in the first job as a skilled worker.

First, Table A1 shows that relative earnings in a cell are positively correlated with the probability of staying with the training firm. Firms want to retain the most productive apprentices as skilled employees. Firms' assessment of apprentices' productivity leads to higher relative payment within a cell and a higher probability to stay with the training firm (Kahn, 2013). This confirms the hypothesis that training firms, on average, retain the most productive apprentices rather than the least productive ones. Leaving a training company can be interpreted as a stigma and training firms have an information advantage regarding the productivity of their apprentices (Katz and Ziderman, 1990; Acemoglu and Pischke, 1998). In this line, Wagner and Zwick (2012) analyse the earnings rank of apprenticeship graduates and their earnings in their first jobs as skilled employees. They show that the higher the share of retained apprentices, the more negatively selected are those who leave the training firm. Moreover, they show that the relative earnings position at the end of the apprenticeship has a significant positive impact not only on skilled entry earnings for those who stay with the training employer but also for the entire group of apprenticeship graduates. When skilled entry earnings reflect the market value (productivity) of an employee, we can conclude that our measure reflects productivity differences of apprentices at the end of the apprenticeship period when training firms are informed about relative productivity of their apprentices.

Second, the earnings rank of stayers at the end of the apprenticeship also predicts first fulltime earnings of stayers (Table A2). Furthermore, a Spearman Rank Correlation Test shows that the earnings rank remains stable between the end of the apprenticeship and the first fulltime employment of stayers within a cell (Table A3).

Obviously, we have to discuss why firms differentiate between the earnings of their apprentices, despite earnings being determined by collective bargaining or other rules that prohibit undercutting of certain earnings levels. Our argument is that training firms use their information advantage on relative productivity differences between their apprentices by 
voluntarily sharing a part of the additional rent created by more able apprentices (Farber and Gibbons, 1986). This could give training enterprises a head start on the labour market after the end of the apprenticeship period because more able apprentices feel more obliged to stay or they are more loyal according to gift exchange considerations (Akerlof, 1984; Mohrenweiser and Zwick, 2013). In addition, an earnings mark-up during apprenticeship training might compensate any exogenous negative utility encountered by apprentices in training firms that could induce them to quit (Acemoglu and Pischke, 1998; Contini et al. 2011; Dustmann and Schönberg, 2012; Kahn, 2013;). Supporting evidence for this hypothesis is that earnings mark-ups increase absolutely and relatively with the duration of the apprenticeship period and reach a maximum just before apprenticeship termination (Figure A1 and Mohrenweiser and Zwick, 2013 for a more detailed discussion).

We interpret the payment difference as relative productivity difference because these apprentices learn the same job and the Vocational Training Act determines tasks that apprentices should perform and learn during each stage of apprenticeship. Therefore, earnings of two apprentices in the same occupation do not differ because both perform different tasks $^{32}$. Moreover, apprenticeship graduates in the same training occupation in one firm are practically identical in terms of observable variables such as age, education, start of apprenticeship and prior working experience ${ }^{33}$. In addition, many employers have explicit financial bonus rules for good grades at vocational school or good performance at work (Ryan, 2011; Backes-Gellner and Oswald, 2012; Ryan et al., 2013). Ryan et al. (2013) present evidence for individual and group-related performance pay for apprentices in 13 out of 18 analysed engineering and retailing firms in Germany.

Furthermore, we collect information about the internal validity of our interpretation of earnings differences in interviews with several personal managers in training firms. Personal managers confirm that all apprentices in the same training year receive the same salary, according to collective agreements. However, many firms pay a number of bonuses for good performance by apprentices. For example, several managers described bonuses for good grades at vocational school and bonuses for project work ${ }^{34}$. Moreover, many firms send their apprentices abroad for some weeks in the final training year. Firms state that apprentices who

\footnotetext{
${ }^{32}$ The earnings definition in the LIAB data entails full-time earnings for apprentices. A fraction of apprentices might receive additional bonuses or work extra hours. This overtime, weekend or shift work payment might partly account for the wage differences between apprentices at the end of the apprenticeship. However, overtime payment is more likely for the more productive apprentices. The imprecision in the earnings measure therefore does not invalidate our measure.

${ }^{33}$ Compare appendix Table A4 which displays a regression of individual characteristics on the earnings of apprentices.

${ }^{34}$ These bonuses may only imprecisely measure the productivity but they are highly correlated to productivity.
} 
are sent abroad are a positive selection, that working abroad therefore is a reward for good performance and that it is accompanied by additional payments according to collective agreements. Finally, Ryan et al. (2013) analyse apprentice payment in a case study and find remarkable earnings variation that is positively correlated with the productivity of apprentices. Backes-Gellner and Oswald (2012) also find earnings bonuses for grades in vocational schools and exploit this finding in a natural experiment.

Table A1: Probability of staying in the training firm.

\begin{tabular}{|l|c|}
\hline & Coef. (z-Value) \\
\hline Earnings deviation from cell mean & $0.04 \quad(2.78)$ \\
\hline Age & $-0.001(0.20)$ \\
\hline Age squared & $-0.001(1.55)$ \\
\hline Male & $0.056(3.67)$ \\
\hline Foreigner & $0.185 \quad(0.91)$ \\
\hline Occupation and year dummies & Yes \\
\hline Observations & 0.01 \\
\hline Pseudo ${ }^{2}$ & 32998 \\
\hline
\end{tabular}

Marginal effects after Probit estimation; dependent variable: 1 apprentice stays in the training firm, 0 apprentice switches immediately after graduation, Standard errors clustered on establishment, t-values in parenthesis. Sample restriction: only firms with at least one staying and one leaving apprenticeship graduate, Source: LIAB longitudinal version 2 1999-2003. 
Table A2: Earnings deviation from establishment/occupation/year mean in the first full-time employment for staying apprenticeship graduates.

\begin{tabular}{|l|c|}
\hline & Coef. (t-Value) \\
\hline $\begin{array}{l}\text { Deviation from establishment/occupation/year } \\
\text { mean at the end of the apprenticeship }\end{array}$ & $0.054 \quad(11.20)$ \\
\hline Age & $-0.361 \quad(0.88)$ \\
\hline Age squared & $0.063 \quad(2.05)$ \\
\hline Male & $1.789 \quad(4.38)$ \\
\hline Foreigner & $5.544 \quad(7.03)$ \\
\hline Constant & $52.66 \quad(10.41)$ \\
\hline Observations & 25509 \\
\hline Adjusted $\mathrm{R}^{2}$ & 0.33 \\
\hline
\end{tabular}

OLS regression; dependent variable: deviation from establishment/occupation/year mean earnings in the first full-time employment. Standard errors clustered on establishment, t-values in parenthesis. Sample restriction: staying apprenticeship graduates in firms with at least two staying apprenticeship graduates, Source: LIAB longitudinal version 2 1999-2003.

Table A3: The stability of stayer wages before and after the end of the apprenticeship period.

\begin{tabular}{|l|l|l|}
\hline Spearman Rank Correlation & Spearman's Rho & 0.3494 \\
Coefficients Test & 0.0000 \\
\hline Kendall's Rank Correlation & Kendall's tau-a & 0.2391 \\
Coefficients Test & 0.2392 \\
& Kendall's tau-b & 0.0000 \\
\hline
\end{tabular}

Comparison between the earnings rank at the end of the apprenticeship and the first full-time employment after the apprenticeship of stayers in the same occupation. Number of observations: 26,609 all stayers in establishments with at least two apprenticeship graduates. Source: LIAB longitudinal version 2, 1999-2003. 
Table A4: Determinants of apprentices’ wages within an establishment, occupation and year cell.

\begin{tabular}{|l|c|}
\hline & Coef. (t-Value) \\
\hline Age & $0.102 \quad(0.18)$ \\
\hline Age squared & $0.004 \quad(0.29)$ \\
\hline Male & $0.204 \quad(1.26)$ \\
\hline Foreigner & $1.093 \quad(3.84)$ \\
\hline Constant & $16.70 \quad(2.56)$ \\
\hline Observations & 32959 \\
\hline Adjusted $\mathrm{R}^{2}$ & 0.24 \\
\hline
\end{tabular}

OLS regression; dependent variable: daily earnings at the end of the apprenticeship. Standard errors clustered on establishment, t-values in parenthesis, Source: LIAB longitudinal version 2 1999-2003.

Figure A1: Development of earnings variance of apprentices within an occupation/establishment/year cell.

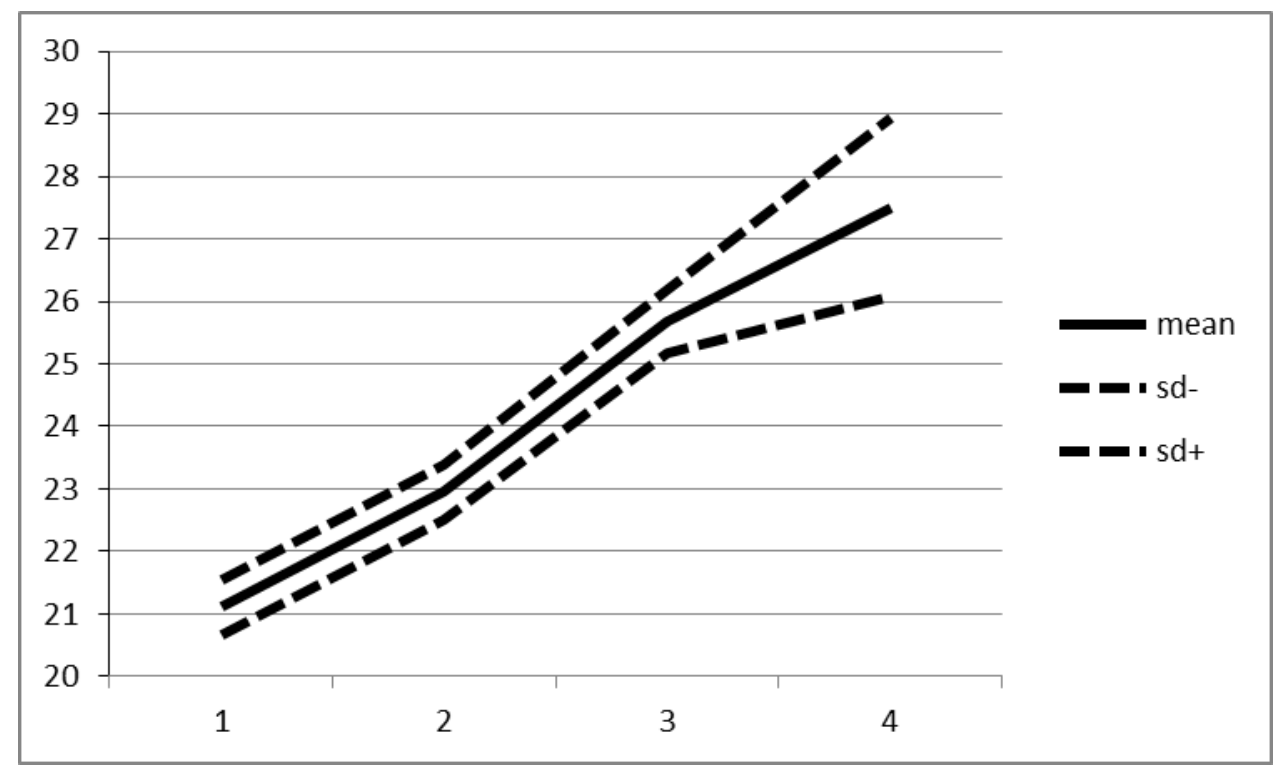

Figure from Mohrenweiser and Zwick (2013), based on the same sample. $N=4223$ cells (Panel A) and N = 6494 cells (Panel B); each cell contains at least three apprentices learning in the same establishment, occupation and graduation year. The data source contains annual earnings. Therefore, year 1 means the time period from start of apprenticeship (usually in August or September) till the end of the calendar year, the following periods are the respective following calendar years, the last period is earnings between January and graduation usually in February or March (3.5 year apprenticeships) and June or July (3-year apprenticeships). Source: LIAB longitudinal version 2, 1999-2006. 


\section{Appendix B: Supplementary material}

Table B1: Descriptive comparisons between stayers and movers.

\begin{tabular}{|l|l|l|c|}
\hline & $\begin{array}{l}\text { In proportion } \\
\text { to all } \\
\text { apprenticeship } \\
\text { graduates }\end{array}$ & $\begin{array}{l}\text { Daily earnings } \\
\text { at the end of the } \\
\text { apprenticeship } \\
\text { in Euro }\end{array}$ & $\begin{array}{l}\text { Daily earnings } \\
\text { at the first } \\
\text { full-time } \\
\text { employment } \\
\text { in Euro }\end{array}$ \\
\hline Stayer & 80.64 & 28.60 & 72.43 \\
\hline Mover within 10 days, same occupation & 7.47 & 28.79 & 69.44 \\
\hline Mover within 10 days, occupational switcher & 3.20 & 26.63 & 57.08 \\
\hline $\begin{array}{l}\text { Mover with unemployment spell of more } \\
\text { than 10 days, same occupation }\end{array}$ & 3.85 & 27,04 & 70.59 \\
\hline $\begin{array}{l}\text { Mover with unemployment spell of more } \\
\text { than 10 days, occupational switcher }\end{array}$ & 4.00 & 25.65 & 52.25 \\
\hline Out of labour force during observation period & 0.84 & 26.99 & --- \\
\hline
\end{tabular}

Sample restrictions: at least two (one moving and one staying) apprenticeship graduates in each establishment/occupation/year cell. N = 32,998, Source: LIAB longitudinal version 2, 1999-2003.

Table B2: Differences in employment growth, number of employees and share of new training positions between raiding firms and poaching victims before and after poaching incidence (period $t$ ).

\begin{tabular}{|c|c|c|c|c|c|c|c|}
\hline & \multicolumn{2}{|c|}{ Employment growth } & \multicolumn{2}{|c|}{ Number of employees } & \multicolumn{2}{|c|}{$\begin{array}{c}\text { Share of new training } \\
\text { positions }\end{array}$} \\
\hline Time & Coef. & T-value & Coef. & T-value & Coef. & t-Value \\
\hline $\mathrm{t}-3$ & -0.105 & 1.69 & 152.93 & 0.46 & 0.017 & 5.07 \\
\hline $\mathrm{t}-2$ & -0.089 & 1.69 & 161.18 & 0.48 & 0.025 & 5.78 \\
\hline $\mathrm{t}-1$ & -0.086 & 2.28 & 27.72 & 0.08 & 0.019 & 4.71 \\
\hline $\mathrm{t}$ & -0.136 & 3.68 & -57.48 & 0.15 & 0.019 & 4.09 \\
\hline $\mathrm{t}+1$ & -0.028 & 1.11 & 37.58 & 0.10 & 0.019 & 4.27 \\
\hline $\mathrm{t}+2$ & 0.018 & 0.79 & -206.41 & 0.51 & 0.018 & 5.12 \\
\hline $\mathrm{t}+3$ & -0.029 & 0.64 & -126.98 & 0.32 & 0.017 & 4.55 \\
\hline
\end{tabular}

OLS Regressions, $\mathrm{N}=215$, further control variables: number of employees, employment growth, churning of skilled employees, proportion of female, foreign and part-time employees, proportion of skilled and high-skilled employees , t-values in parenthesis. Source: LIAB longitudinal version 2 1999-2003. 
Table B3: Descriptive differences between poaching victims and control firms that train apprentices in blue-collar manufacturing occupations.

\begin{tabular}{|c|c|c|}
\hline & $\begin{array}{l}\text { Poaching } \\
\text { victims }\end{array}$ & Control group \\
\hline Number of employees & $\begin{array}{c}2888 \\
(5069)\end{array}$ & $\begin{array}{c}994 \\
(1886)\end{array}$ \\
\hline $\begin{array}{l}\text { Employee growth to previous year } \\
\text { in per cent }\end{array}$ & $\begin{array}{l}-0.042 \\
(0.143)\end{array}$ & $\begin{array}{c}0.001 \\
(0.102)\end{array}$ \\
\hline $\begin{array}{l}\text { First quartile earnings for skilled } \\
\text { employees } \\
\text { (daily earnings) }\end{array}$ & $\begin{array}{c}97.34 \\
(11.40)\end{array}$ & $\begin{array}{c}85.58 \\
(15.38)\end{array}$ \\
\hline $\begin{array}{l}\text { Median earnings for skilled employees } \\
\text { (daily earnings) }\end{array}$ & $\begin{array}{l}111.44 \\
(14.99)\end{array}$ & $\begin{array}{c}96.57 \\
(17.97) \\
\end{array}$ \\
\hline $\begin{array}{l}\text { Third quartile earnings for skilled } \\
\text { employees } \\
\text { (daily earnings) }\end{array}$ & $\begin{array}{l}130.79 \\
(18.92)\end{array}$ & $\begin{array}{l}112.98 \\
(23.30)\end{array}$ \\
\hline Churning of skilled employees & $\begin{array}{c}0.309 \\
(0.251)\end{array}$ & $\begin{array}{c}0.321 \\
(0.247)\end{array}$ \\
\hline Share of apprentices & $\begin{array}{c}0.100 \\
(0.095)\end{array}$ & $\begin{array}{c}0.062 \\
(0.048)\end{array}$ \\
\hline Share of female employees & $\begin{array}{c}0.229 \\
(0.136)\end{array}$ & $\begin{array}{c}0.219 \\
(0.169)\end{array}$ \\
\hline Share of foreign employees & $\begin{array}{c}0.067 \\
(0.057)\end{array}$ & $\begin{array}{c}0.075 \\
(0.087)\end{array}$ \\
\hline Share of part-time employees & $\begin{array}{c}0.056 \\
(0.043)\end{array}$ & $\begin{array}{c}0.053 \\
(0.072)\end{array}$ \\
\hline Share of skilled employees & $\begin{array}{c}0.633 \\
(0.133)\end{array}$ & $\begin{array}{c}0.693 \\
(0.147)\end{array}$ \\
\hline Share of high-skilled employees & $\begin{array}{c}0.152 \\
(0.095)\end{array}$ & $\begin{array}{c}0.094 \\
(0.100)\end{array}$ \\
\hline Number of observations & 54 & 2214 \\
\hline
\end{tabular}

Mean and standard deviation in parenthesis; identification based on the longitudinal version 2 of the LIAB, source: EHB 1999-2003. 